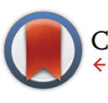

CrossMark $\leftarrow$ click for updates

Cite this: Dalton Trans., 2016, 45 6856

Received 14th December 2015, Accepted 5th February 2016

DOI: $10.1039 / c 5 d t 04870 b$

www.rsc.org/dalton

\section{Triphos derivatives and diphosphines as ligands in the ruthenium-catalysed alcohol amination with $\mathrm{NH}_{3} \dagger$}

\author{
N. Nakagawa, ${ }^{a}$ E. J. Derrah, ${ }^{a}$ M. Schelwies, ${ }^{b}$ F. Rominger, ${ }^{c}$ O. $\operatorname{Trapp}^{c}$ and T. Schaub*a,b \\ The ruthenium-triphos and diphosphine-catalysed amination of alcohols with ammonia is reported. \\ Various types of triphos derivatives with electron-donating functional group were synthesized and used as \\ ligands in the Ru-catalysed alcohol amination with $\mathrm{NH}_{3}$. The triphos derivatives are effective for the for- \\ mation of primary amines. On the other hand, if hemilabile diphosphines as tridentate ligands are used, \\ mixtures of secondary-along with primary amines are obtained. It was found that even simple diphos- \\ phines can be used as ligands for the selective formation of the secondary amines. The diphosphine \\ system allows a new entry to the Ru-catalysed formation of secondary amines.
}

\section{Introduction}

Amines are important building blocks in the manufacture of pharmaceuticals and agrochemicals. ${ }^{1}$ Intensive research has focused on the selective formation of primary, secondary and tertiary amines. ${ }^{2}$ One of the most straightforward and environmentally-friendly methods is the amination of alcohols using cheap and abundant ammonia $\left(\mathrm{NH}_{3}\right)$, which represents an atom efficient route towards this valuable class of organic compounds, along with water as the sole by-product. ${ }^{3}$ The amination of alcohols with ammonia is performed with heterogeneous catalysts on industrial scale. Using heterogeneous catalysts, it is in many cases difficult to control the selectivity as harsh reaction conditions are required. ${ }^{1 c}$ During the last decade, the amination of alcohols has been further developed with a series of homogeneous catalysts. ${ }^{4}$ In particular, ruthenium catalysts were identified to exhibit a high performance for the selective formation of primary amines ${ }^{5}$ and secondary amines. ${ }^{6}$ The combination of a ruthenium pre-catalyst and the tridentate phosphine ligand 1,1,1-tris(diphenylphosphinomethyl)ethane $\mathbf{1}$ (= triphos) was first published as one of the candidates in the alcohol amination by Beller and co-workers $^{7 a}$ and investigated in detail by our laboratory

\footnotetext{
${ }^{a}$ Catalysis Research Laboratory (CaRLa), Im Neuenheimer Feld 584, D-69120 Heidelberg, Germany. E-mail: thomas.schaub@basf.com

${ }^{b}$ Synthesis \& Homogeneous Catalysis, BASF SE, Carl-Bosch-Straße 38, D-67056 Ludwigshafen, Germany

'Organisch-Chemisches Institut, Ruprecht-Karls-Universität Heidelberg, Im Neuenheimer Feld 270, D-69120 Heidelberg, Germany

$\dagger$ Electronic supplementary information (ESI) available. CCDC 1440322-1440325. For ESI and crystallographic data in CIF or other electronic format see DOI: $10.1039 / \mathrm{c} 5 \mathrm{dt} 04870 \mathrm{~b}$
}

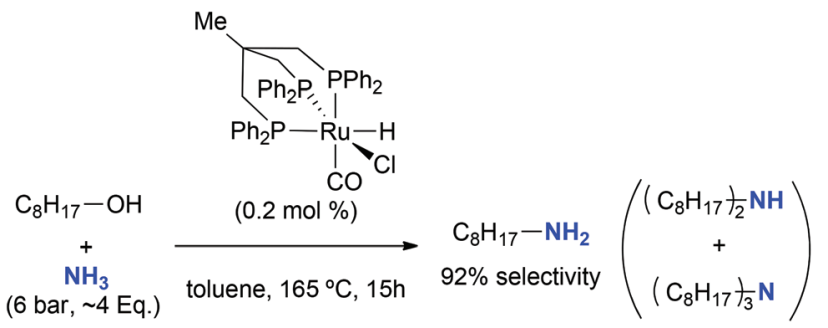

Scheme 1 Ruthenium-triphos-catalysed amination of 1-octanol with ammonia. $^{7 b}$

(Scheme 1). ${ }^{7 b}$ We disclosed that the catalytic active species is a cationic ruthenium-triphos complex through experimental and computational investigations. Our previous report on this ruthenium catalysis described only the use of the commercial available triphos 1 and effects of other phosphine derivatives have still remained undisclosed and undeveloped. We herein report the synthesis and evaluation of triphos derivatives and the corresponding ruthenium complexes in order to gain an insight how variations of the triphos scaffold influence the ruthenium-catalysed amination of alcohols with $\mathrm{NH}_{3}$. Our approach was to alter the coordination sphere of triphos-type $\mathrm{Ru}$-complexes in order to change the selectivities in the corresponding amination reactions.

\section{Results and discussion}

\section{Ligands}

To evaluate the ligand influence on the catalytic performance of the ruthenium-catalysed amination of 1-octanol with $\mathrm{NH}_{3}$, 
<smiles>CC(CPc1ccccc1)(Cc1ccccc1)Cc1ccccc1</smiles><smiles>CC(CP)(Cc1ccccc1)CP(=O)(O)c1ccccc1</smiles><smiles>CC(CP)(CP(=O)(O)O)CP(=O)(O)O</smiles>

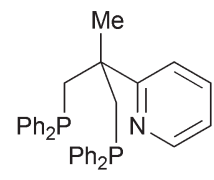

4

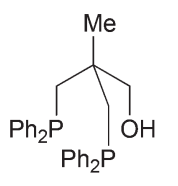

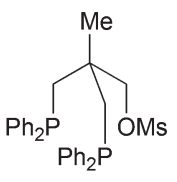

6
Fig. 1 Triphos 1, triphos derivatives 2 and 3, and diphosphines with electron-donating functional groups 4-6 used in this work.

(a) Synthesis of $\mathbf{2}$<smiles>CC1(CO)COC1</smiles>

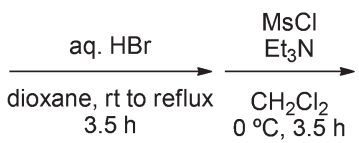

$\mathrm{MsO}$ $7,78 \%$ (2 steps)

1) $\mathrm{LiPPh}_{2}, \mathrm{THF},-40{ }^{\circ} \mathrm{C}, 2 \mathrm{~h}$ 2) $\mathrm{LiPPh}_{2}, \mathrm{THF}, 0^{\circ} \mathrm{C}$ to rt, $16 \mathrm{~h}$

3) $\mathrm{BH}_{3} \cdot \mathrm{SMe}_{2}, \mathrm{THF}, \mathrm{rt}, 1 \mathrm{~h}$
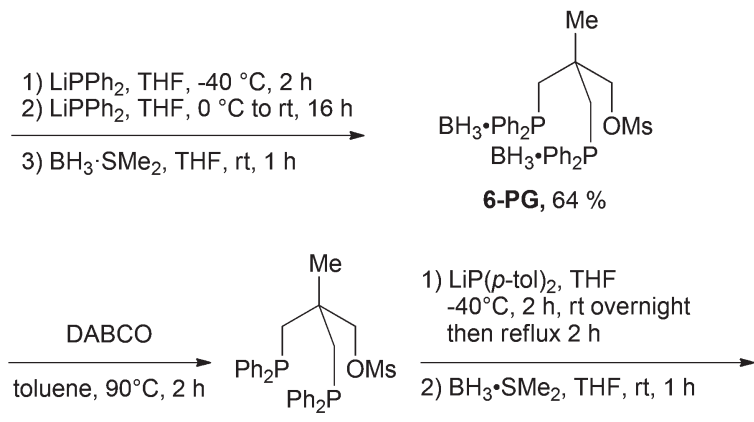

6, $66 \%$
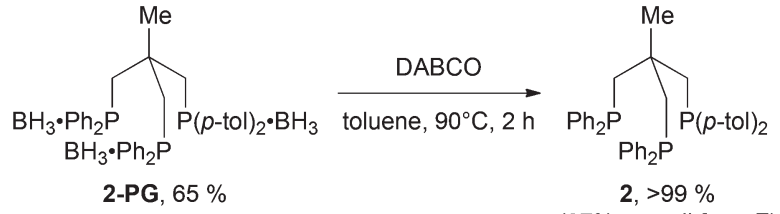

2, >99\% ( $27 \%$ overall from 7 )

(b) Synthesis of 3

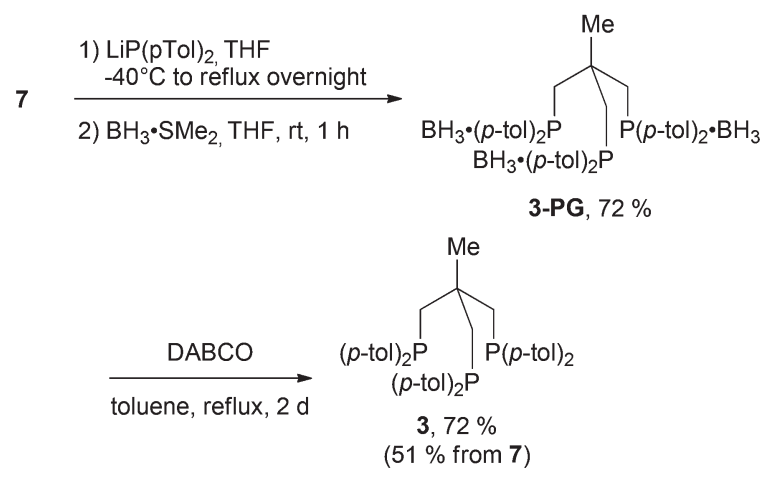

Scheme 2 Optimised synthetic protocol for triphos derivatives. the following triphos derivatives were used: triphos $\mathbf{1}$, the newly synthesised phenyl-p-tolyl-mixed triphos derivative 2 , and the all- $p$-tolyl triphos derivative $\mathbf{3}$ (obtained via a modified procedure). ${ }^{8}$ We also examined diphosphines with an electrondonating functional group such as a pyridyl substituted derivative 4 , which is potentially hemilabile ligand, ${ }^{9}$ as well as oxygen-substituted ones $5^{10}$ and 6 (Fig. 1).

\section{Synthesis of triphos derivatives via modified protocol}

$C_{3 \mathrm{~V}}$ symmetrical triphos-type ligands such as 3 can be obtained using 1,1,1-tris(chloromethyl)ethane as a starting material. A route to $C 1$ symmetric variants of the ligand with three different phosphine donors was reported by Huttner and Helmchen. ${ }^{8}$ However, since we were only interested altering one of the three donor groups of triphos, we chose 7 as key intermediate $^{10 a}$ in our synthesis (Scheme 2). The substitution reaction of $\mathrm{CH}_{2} \mathrm{C}\left(\mathrm{CH}_{2} \mathrm{OMs}\right)_{2}\left(\mathrm{CH}_{2} \mathrm{Br}\right) 7$ with an excess amount of lithium diphenylphosphide, followed by borane protection afforded a monomesyl diphosphine-borane compound 6-PG in $64 \%$ yield (Scheme $2 \mathrm{a}$ ). After deprotection with DABCO, the intermediate 6 was obtained in $66 \%$ yield. We repeated this sequence using lithium di( $p$-tolyl)phosphide with monomesylate 6 and obtained the unsymmetrical triphos-borane 2-PG. The structure of 2-PG was confirmed by X-ray analysis (Fig. 2). Deprotection of 2-PG afforded the unsymmetrical triphos 2 in $27 \%$ overall yield. The same protocol was applied to the synthesis of all- $p$-tolyl triphos 3 (51\% overall yield, Scheme $2 \mathrm{~b}) .{ }^{11}$

\section{Synthesis of ruthenium complexes}

Ruthenium complexes of the triphos derivatives 1-3 were prepared according to the reported protocol for Ru-triphos complex A (Scheme 3). ${ }^{12}$ When using 2 as a ligand, a mixture of three isomers is formed. ${ }^{31} \mathrm{P}-\mathrm{NMR}$ indicates that the three isomers differ in the position of the tolyl moiety. Elemental ana-

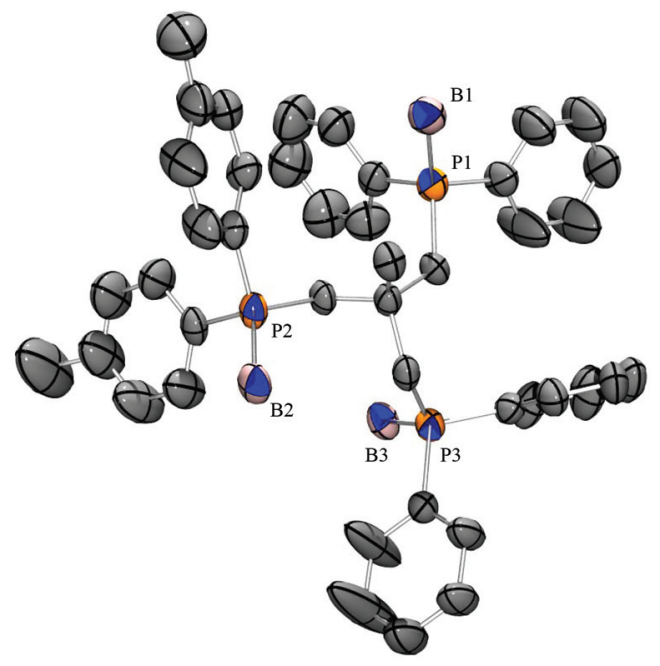

Fig. 2 ORTEP drawing of the borane-adduct 2-PG where all nonhydrogen atoms are represented by Gaussian ellipsoids at the $50 \%$ probability level. All hydrogen atoms have been omitted for clarity. 


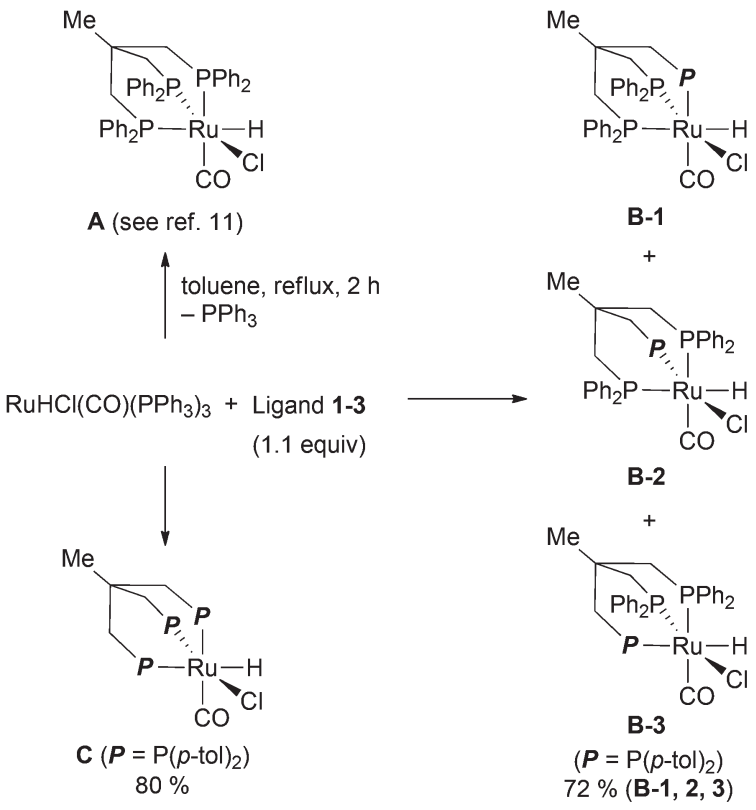

Scheme 3 Synthesis of triphos-type ruthenium complexes A-C.

lysis confirms the composition of the mixture of $\mathbf{B}-\mathbf{1}, \mathbf{B}-\mathbf{2}$, and B-3. In case of the all-tolyl substituted ligand 3, only one complex (C) is formed like in the synthesis of $\mathbf{A}$. The structure of $\mathrm{C}$ was determined by $\mathrm{X}$-ray analysis (Fig. 3). The distance of $\mathrm{Ru}-$ $\mathrm{P}$ bonds in $\mathrm{C}$ is the range of $2.27-2.38 \AA$ which is similar like in the reported structure for $\mathrm{RuHCl}(\mathrm{CO})\left(\right.$ triphos) $\mathbf{A} .^{13}$

We also conducted the preparation of the corresponding ruthenium complexes with pyridyl substitued diphosphine $4 .{ }^{9}$ Using this ligand, a mixture of three complexes was obtained:

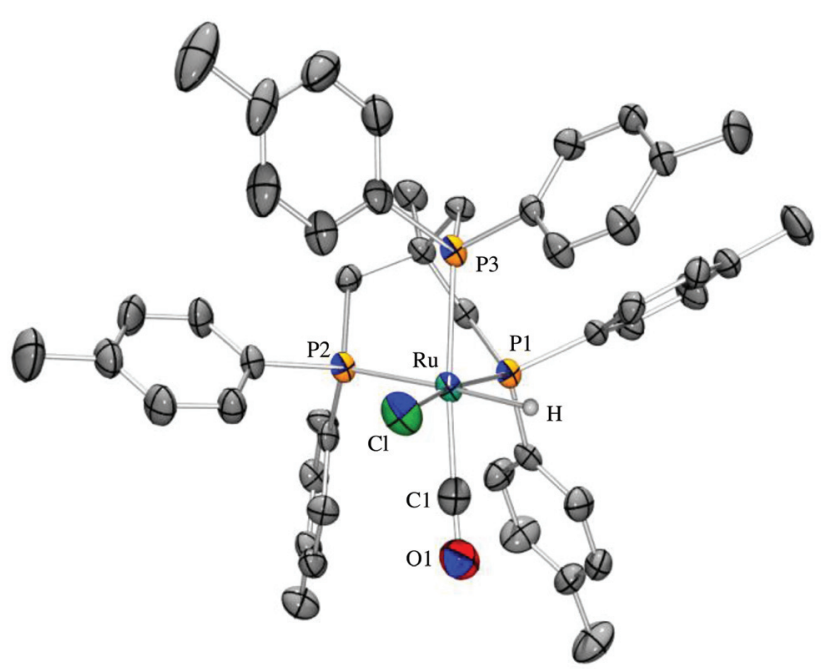

Fig. 3 ORTEP drawing of the ruthenium complex $\mathrm{C}$ where all non-hydrogen atoms are represented by Gaussian ellipsoids at the $50 \%$ probability level and all hydrogen atoms have been removed for simplicity. Selected bond lengths $(\AA)$ and angles $\left({ }^{\circ}\right)$ of $\mathrm{C}: \mathrm{Ru}-\mathrm{P} 1=2.2740(12) ; \mathrm{Ru}-\mathrm{P} 2=$ 2.3847(12); $\mathrm{Ru}-\mathrm{P3}=2.3840$ (13); $\mathrm{Ru}-\mathrm{H}=1.88$ (3); $\mathrm{Ru}-\mathrm{Cl}=2.5000$ (13); $\mathrm{P} 1-$ $\mathrm{Ru}-\mathrm{P} 2$ = 88.31(4); P2-Ru-P3 = 86.94(4); P3-Ru-P1 = 88.67(4).

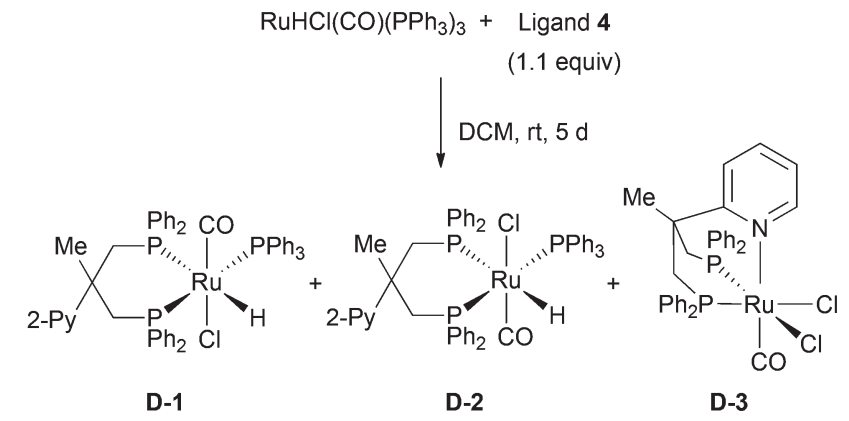

Scheme 4 Preparation of pyridyl diphosphine ruthenium complexes D-1, D-2, and D-3.

the two isomers D-1 and D-2 as well as the dichloro ruthenium species D-3 (Scheme 4). The structure of D-3 was confirmed by X-ray analysis (Fig. 4). Regarding the structure of D-3, the carbonyl ligand is located trans to the pyridyl moiety. Although the reaction pathway towards D-3 is not confirmed, we propose that the chlorine atom on $\mathbf{D}-3$ was derived from the $\mathrm{CH}_{2} \mathrm{Cl}_{2}$ solvent through the chlorine abstraction by ruthenium hydride species. Under these conditions, selective formation and complete separation of the three isomers turned out to be difficult. In addition, we failed to obtain the ruthenium-pyridyl diphosphine complex selectively in toluene as solvent. Therefore, we used the pyridyl diphoshine 4 directly in combination with $\left[\mathrm{Ru}\left(\mathrm{PPh}_{3}\right)_{3}(\mathrm{CO}) \mathrm{HCl}\right]$ in the amination reaction to generate the desired complexes in situ (vide infra).

We were also successful to synthesise a novel hydroxyl-containing ruthenium complex $\mathbf{E}$ from $\mathbf{5}^{10}$ (Scheme 5). The structure of $\mathbf{E}$ was confirmed by X-ray analysis (Fig. 5). One $\mathrm{PPh}_{3}$ ligand from the precursor remains on ruthenium which is con-

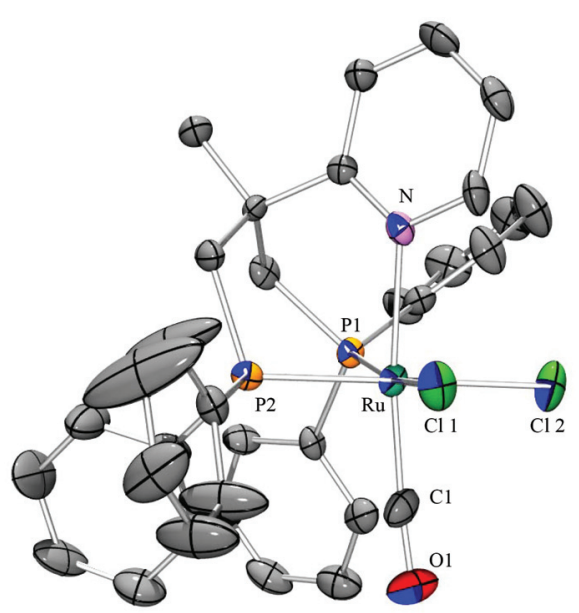

Fig. 4 ORTEP drawing of the dichloro ruthenium complex D-3 where all non-hydrogen atoms are represented by Gaussian ellipsoids at the $50 \%$ probability level. All hydrogen atoms and coordinating solvent have been omitted for clarity. Selected bond lengths $(\AA)$ and angles $\left(^{\circ}\right)$ of D-3: $\mathrm{Ru}-\mathrm{P} 1$ = 2.2970(14); $\mathrm{Ru}-\mathrm{P} 2$ = 2.2844(15); Ru-N = 2.178(4); Ru-Cl1 = 2.4314(13); $\mathrm{Ru}-\mathrm{Cl} 2$ = 2.4775(14); $\mathrm{P} 1-\mathrm{Ru}-\mathrm{P} 2=87.65(5) ; \mathrm{P} 1-\mathrm{Ru}-\mathrm{N}=$ 83.76(11); P2-Ru-N = 90.25(11). 

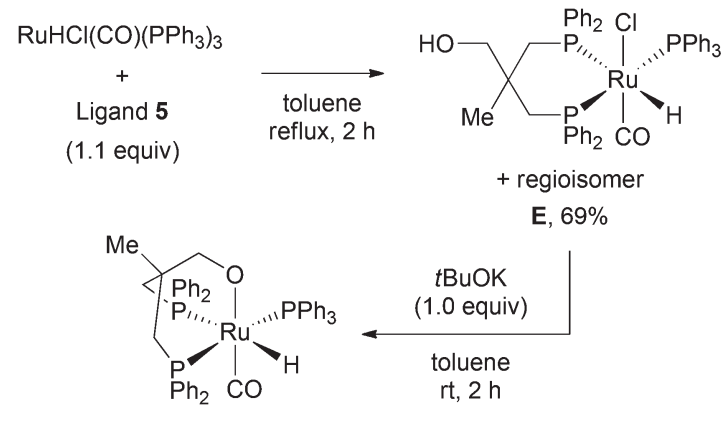

F, $75 \%$

Scheme 5 Synthesis of hydroxyl-containing diphosphine ruthenium complex $\mathrm{E}$ and reaction between complex $\mathrm{E}$ and $t \mathrm{BuOK}$.

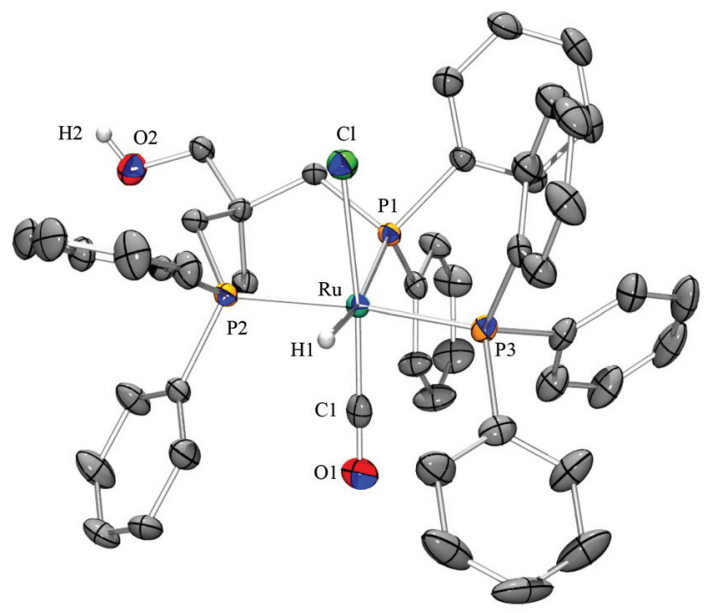

Fig. 5 ORTEP drawing of hydroxyl-containing diphosphine ruthenium complex E where all non-hydrogen atoms are represented by Gaussian ellipsoids at the $50 \%$ probability level. All hydrogen atoms and coordinating solvent have been omitted for clarity. Selected bond lengths ( $\AA$ ) and angles $\left({ }^{\circ}\right)$ of $\mathrm{E}: \mathrm{Ru}-\mathrm{P} 1=2.4279(10) ; \mathrm{Ru}-\mathrm{P} 2=2.3586(10) ; \mathrm{Ru}-\mathrm{P} 3=$ 2.3806(11); $\mathrm{Ru}-\mathrm{H}=1.62(5) ; \mathrm{Ru}-\mathrm{Cl}=2.4725(11) ; \mathrm{P} 1-\mathrm{Ru}-\mathrm{P} 2$ = 94.38(3); P3-Ru-P1 = 100.04(4)

sistent with reported $\mathrm{RuHCl}(\mathrm{CO}) \mathrm{PPh}_{3}$ (diphosphine) complexes. $^{5 e, g}$ The hydroxyl group orients to the opposite direction from the ruthenium centre, thus it seems to be an unsuitable coordinating group to achieve a tridentate coordination mode. In order to facilitate a coordination of the oxygen atom, the ruthenium complex $\mathbf{E}$ was treated with potassium tert-butoxide (Scheme 5). The red powder obtained was assigned as the alkoxo ruthenium complex $\mathbf{F}$ by ${ }^{1} \mathrm{H}$ and ${ }^{31} \mathrm{P}$ NMR spectra as well as LIFDI mass spectroscopy. It is conceivable that under a basic ammonia atmosphere of the alcohol amination the alkoxo complex $\mathbf{F}$ will be formed in situ from $\mathbf{E}$.

\section{Catalytic investigations}

In order to investigate the ligand effects, the ruthenium-catalysed amination of 1-octanol with $\mathrm{NH}_{3}$ was conducted for the above described ligands 1-6 (Table 1). As previously reported by our group, ${ }^{7}$ the ruthenium-triphos complex $\mathbf{A}$ showed a high catalytic performance towards octylamine $\mathbf{8}$ along with small amounts of the secondary and tertiary amines $\mathbf{9}$ and $\mathbf{1 0}$ (entry 1). Note that it is unnecessary to use the isolated ruthenium catalyst A: the in situ prepared ruthenium-triphos catalyst showed the same activity and selectivity as A (entry 2). In the absence of any additional phosphine, the amination products 8 to 10 were not obtained (entry 3). When the $p$-tolyl-substituted triphos derivatives 2 and 3 were used instead of $\mathbf{1}$, it was found that the selectivity towards the primary amine is slightly shifted to dioctylamine 9 (entries 4 and 5). The use of the pyridyl diphosphine $\mathbf{4}$, a potentially hemilabile ligand, led to the formation of dioctylamine $\mathbf{9}$ (entry 6). The amination reactions using the hydroxyl-diphosphine complex $\mathbf{E}$ and its alkoxo complex $\mathbf{F}$ were sluggish and the dioctylamine $\mathbf{9}$ is formed in good selectivity (entries 7 and 8). These results can be interpreted as the complex $\mathbf{E}$ probably converts into the alkoxo complex $\mathbf{F}$ through deprotonation of the hydroxyl group under the basic conditions of the amination. When the mesyl diphosphine $\mathbf{6}$, which is the synthetic intermediate of the ligands $\mathbf{2}$ and $\mathbf{3}$, was used as a ligand, dioctylamine $\mathbf{9}$ is formed in good selectivity (entry 9). Probably the mesyl group (OMs) will be displaced by the amino group $\left(\mathrm{NH}_{2}\right)$ via nucleophilic substitution under the ammonia atmosphere of the amination reaction. ${ }^{11}$ To our surprise, even simpler diphosphines, such as dpppdmp (1,3-bis(diphenylphosphino)-2,2-dimethylpropane, $\left.\mathrm{Ph}_{2} \mathrm{PCH}_{2} \mathrm{C}\left(\mathrm{CH}_{3}\right)_{2} \mathrm{CH}_{2} \mathrm{PPh}_{2}\right)$ and dppp (1,3-bis (diphenylphosphino)propane, $\mathrm{Ph}_{2} \mathrm{PCH}_{2} \mathrm{CH}_{2} \mathrm{CH}_{2} \mathrm{PPh}_{2}$ ), were found to be good ligands for the preferable formation of dioctylamine 9 (entries 10 and 11). ${ }^{14,15}$ Finally, the highly selective formation of dioctylamine $\mathbf{9}$ was achieved with dppp at a higher substrate concentration (entries 12 and 13).

The reduced amount of toluene significantly affected the formation of the secondary amine. In order to get more insights in the reaction, we examined the reaction profile by analysing the reaction mixture at several reaction times (1-8 h; Fig. 6) ${ }^{16}$ The obtained curves showed that there is no significant induction period, and that the amount of octylamine $\mathbf{8}$ and dioctylamine 9 increases as time elapses without decomposing or interconverting into the other products. We also confirmed the formation of small amount of octyloctan-1-imine 11, which is assumed to be the intermediate before dioctylamine $\mathbf{9}$ is formed. The imine $\mathbf{1 1}$ is propably reactive to a $\mathrm{Ru}-\mathrm{H}$ species to produce dioctylamine $\mathbf{9}$ through hydrogenation.

The possible mechanism is described in Scheme 6. As we postulated in the previous report, ${ }^{7}$ the selective mono-alkylation of ammonia using ruthenium-triphos complexes involves the formation of cationic ruthenium-triphos intermediates as active species (Scheme 6a). Among the triphos derivatives, the different ratio between the primary and secondary amines can originate from the difference of electron negativity of $\mathrm{P}$ atom. In the case of hemilabile diphosphines and simple diphosphines, the formation of the secondary amine is preferred under the same reaction conditions. This observation can be explained by considering a different mechanism. As Vogt and co-workers disclosed the mechanism on the amination of cyclohexanol using xantphos, ${ }^{5 g}$ the dissociation of the remaining 
Table 1 Effect of altering the phosphine ligand

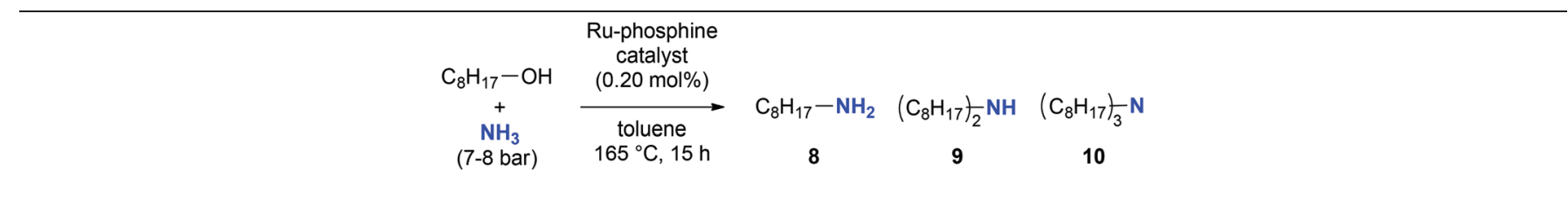

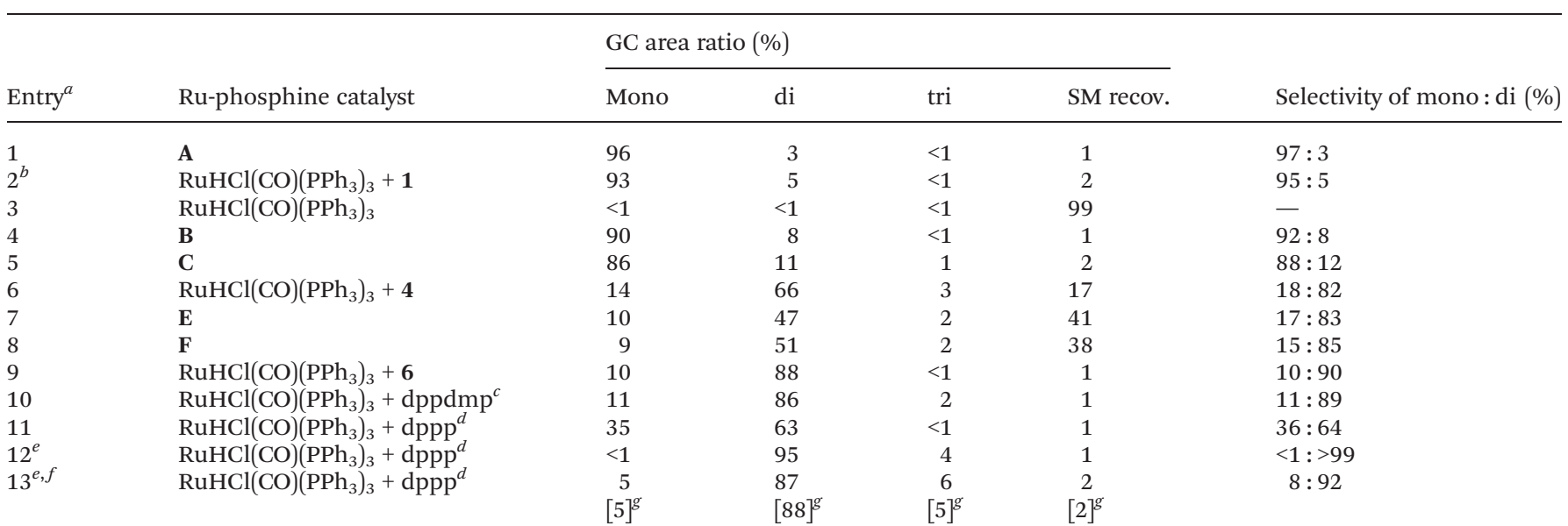

${ }^{a}$ 1-Octanol (3.0 g, $\left.23.6 \mathrm{mmol}\right)$ and $17 \mathrm{~mL}$ of toluene was used. ${ }^{b} 0.22 \mathrm{~mol} \%$ of ligand was used. ${ }^{c} \mathrm{dppdmp}=1,3$-bis(diphenylphosphine)-2,2dimethylpropane. ${ }^{d} \mathrm{dppp}=1,3$-bis(diphenylphosphino)propane. ${ }^{e} 6 \mathrm{~mL}$ of toluene was used as a solvent. ${ }^{f} \mathrm{p}\left(\mathrm{NH}_{3}\right)=4$ bar $(\sim 52 \mathrm{mmol}) .{ }^{g} \mathrm{The}$ calibrated GC yields against hexadecane as an internal standard.

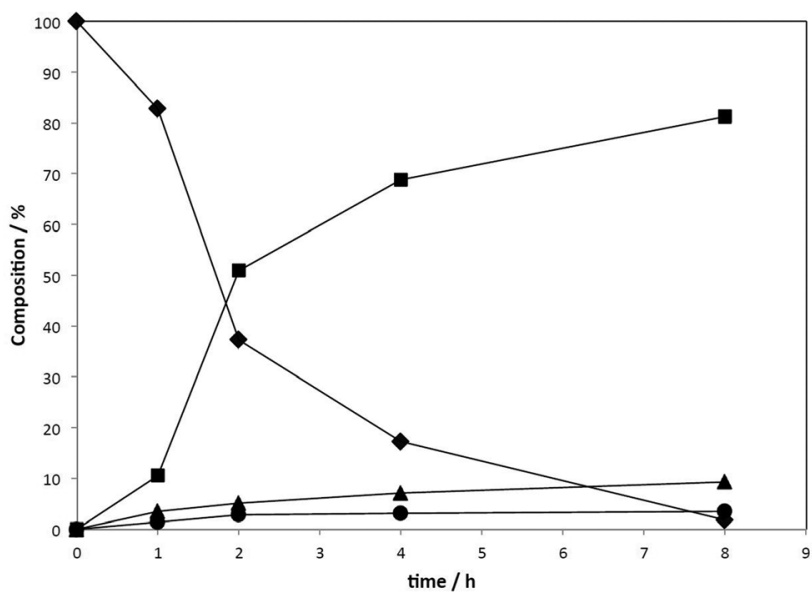

Fig. 6 Reaction profile for the Ru-dppp-catalysed amination of octanol with $\mathrm{NH}_{3}$. Reaction conditions: in a premix autoclave $(60 \mathrm{~mL}$ stainless steel), 1-octanol $(3.0 \mathrm{~g}, 24 \mathrm{mmol})(\diamond), \mathrm{p}\left(\mathrm{NH}_{3}\right)=4$ bar $(0.9 \mathrm{~g}, 53 \mathrm{mmol}$ of $\left.\mathrm{NH}_{3}\right)$, RuHCl(CO) $\left(\mathrm{PPh}_{3}\right)_{3}(45 \mathrm{mg}, 0.047 \mathrm{mmol})$, dppp $(21 \mathrm{mg}$, $0.052 \mathrm{mmol})$, and toluene $(6 \mathrm{~mL})$. Observed products: octylamine $8(\mathbf{\Delta})$, dioctylamine $9(\square)$, and octyloctan-1-imine $11(\bullet)$. Trioctylamine 10 was observed in $2-4 \%$ GC area ratio in each reaction time.

$\mathrm{PPh}_{3}$ can play an important role (Scheme 6b). Although the mechanism of dialkylation is still unclear, it is possible to consider that dissociation of $\mathrm{PPh}_{3}$ and chloride can provide more vacant sites on the ruthenium than in the triphos systems. The transient ketone or imine can coordinate at the vacant site and incorporate in the further alkylation. When octylamine 8 as a starting material is used instead of 1-octanol, the formation of the dioctylamine 9 was only observed in small amounts (eqn (1)). Therefore, it is conceivable that the ruthenium-diphosphine complex possesses a poor ability on dehydrogenation of the primary amine 8. Presumably, in situ generated ketone or imine (from the starting alcohol) are the reactants for the dilakylation.

$$
\begin{aligned}
& \mathrm{RuHCl}(\mathrm{CO})\left(\mathrm{PPh}_{3}\right)_{3} \\
& \text { (0.20 mol\%) }
\end{aligned}
$$

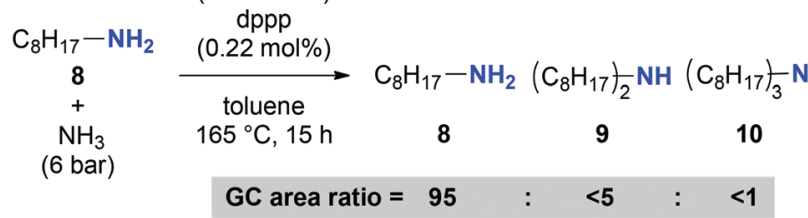

\section{Conclusions}

A series of ruthenium-complexes bearing triphos derivatives and diphosphines with the electron-donating functional group were prepared and examined for the amination of primary alcohols with $\mathrm{NH}_{3}$. Deviating the P-substituents on the triphos scaffold slightly affects the ratio of mono- and dialkylamines, but these triphos derivatives are basically effective for the formation of the primary amines. The reaction mechanism of mono-alkylation can involve the formation of the cationic ruthenium complex based on our previous investigations. On the other hand, the use of hemilabile diphosphines leads to a mixture of the primary and secondary amines. It seems to be clearer after these results, that the origin of high selectivities towards the primary amines is related to the very stable ligand spheres of $\mathrm{Ru} /$ triphos and the Milstein type $\mathrm{Ru} /$ pincer 
(a) With triphos-type ligands (based on Ref. 7b)

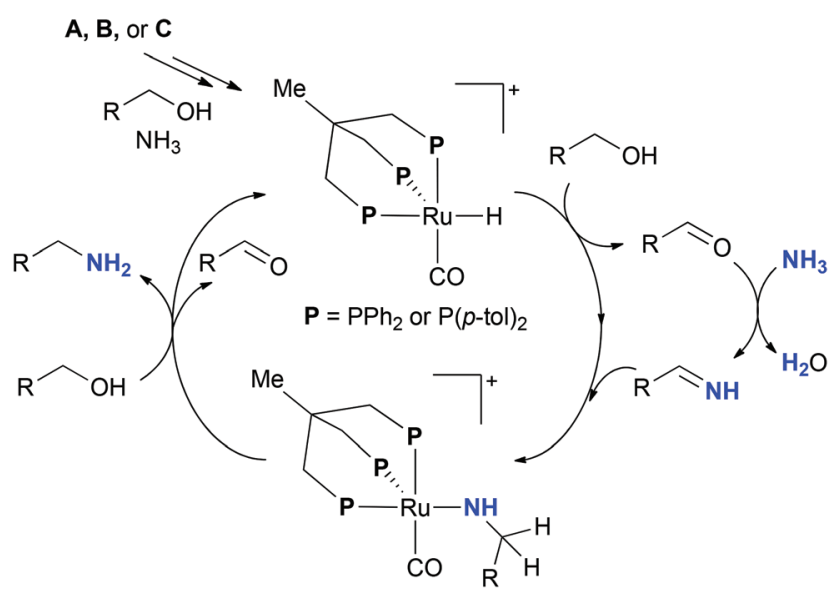

(b) With diphosphine ligands (based on Ref. $5 \mathrm{~g}$ )

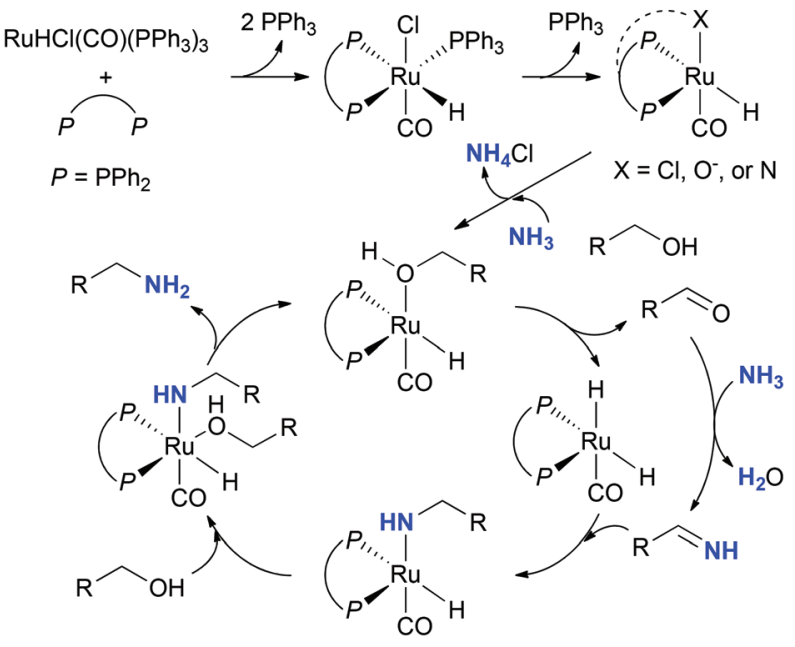

Scheme 6 Simplified possible catalytic cycles.

systems. ${ }^{5 a, h}$ The selective formation of the secondary amine was finally realized by using simple dppp as the ligand. The reaction mechanism of the ruthenium-diphosphine system can be influenced by dissociation of attaching $\mathrm{PPh}_{3}$ which is different to the triphos-based systems. So far, the preparation of secondary amines from alcohols with $\mathrm{NH}_{3}$ using homogeneous catalysts has been achieved by Milstein and co-worker with $\mathrm{Ru}$ catalyst, ${ }^{6}$ or by Fujita, Yamaguchi, and co-workers as well as in previous work from our laboratory using Ir catalysts. ${ }^{17}$ Compared with these studies, our current diphosphine system offers a simple protocol for the preparation of diamines with commercially available catalysts.

\section{Experimental}

\section{General considerations}

All reactions were carried out under a positive pressure of argon in an MBraun glovebox or using standard Schlenk line techniques. All nondeuterated solvents were dried using an MBraun SPS-800 solvent purification system and degassed prior to use. 3-Methyl-3-oxetanemethanol (a precursor of 7), and 1-octanol were purchased from Aldrich and distilled prior to use. Di-p-tolyl and di-phenylphosphines were purchased from ABCR, RuHCl(CO) $\left(\mathrm{PPh}_{3}\right)_{3}$ was supplied by BASF and used without further purification. All other products were purchased from Aldrich and used without further purification. Liquid reagents including deuterium solvents were distilled prior to use, and all others were used without further purification. ${ }^{1} \mathrm{H},{ }^{13} \mathrm{C}\left\{{ }^{1} \mathrm{H}\right\}$, and ${ }^{31} \mathrm{P}\left\{{ }^{1} \mathrm{H}\right\} \quad$ NMR spectra were recorded on a Bruker Avance 200, 400, or $600 \mathrm{MHz}$ spectrometer. ${ }^{1} \mathrm{H}$ and ${ }^{13} \mathrm{C}$ chemical shifts are reported relative to residual solvent signals of $\mathrm{CD}_{2} \mathrm{Cl}_{2}(5.32$ and $54.0 \mathrm{ppm})$ and THF- $d_{8}$ (5.38 and $\left.67.21 \mathrm{ppm}\right) .{ }^{31} \mathrm{P}\left\{{ }^{1} \mathrm{H}\right\}$ chemical shifts are referenced to an external $85 \%$ solution of phosphoric acid. The ${ }^{13} \mathrm{C}$ NMR data were assigned by HSQC and HMBC spectra. FAB and HR mass spectrometry was measured at the Mass Spectrometry Facility (Institute of the Organic Chemistry, University Heidelberg). Gas chromatography was performed on an Agilent $6890 \mathrm{~N}$ modular GC base equipped with a split-mode capillary injection system and a flame ionization detector using a BGB-5 capillary column (Agilent 122-1033; $30 \mathrm{~m} \times$

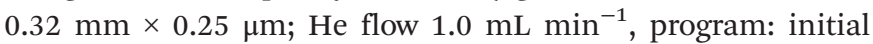
$50{ }^{\circ} \mathrm{C}$ for $2 \mathrm{~min}$, ramp $6^{\circ} \mathrm{C} \mathrm{min}^{-1}, 300{ }^{\circ} \mathrm{C}$ for $10 \mathrm{~min}$ ). Starting materials and products had the following retention times: octylamine ( $\left.t_{\mathrm{R}}=14.54 \mathrm{~min}\right)$, 1-octanol $\left(t_{\mathrm{R}}=15.16 \mathrm{~min}\right)$, dioctylamine $\left(t_{\mathrm{R}}=31.34 \mathrm{~min}\right)$, and trioctylamine $\left(t_{\mathrm{R}}=41.71 \mathrm{~min}\right)$. Elemental analysis were performed in the "Mikroanalytisches Laboratorium der Chemischen Institute der Universität Heidelberg". X-ray structures were solved by derect methods and refined against $F^{2}$ with a full-matrix least squares algorithm by using the SHELXTL (version 2014/7) software package. ${ }^{18}$ Intensities were corrected for Lorentz and polarisation effects. ${ }^{19}$ CCDC 1440322 (2-PG), 1440323 (C), 1440324 (D-3), and 1440325 (E) contain the supplementary crystallographic data for this paper.

\section{Synthesis of $\mathrm{H}_{3} \mathrm{CC}\left(\mathrm{CH}_{2} \mathrm{OMs}\right)_{2}\left(\mathrm{CH}_{2} \mathrm{Br}\right)(7)$}

A $100 \mathrm{~mL}$ round-bottom Schlenk flask was charged with $25 \mathrm{~mL}$ dioxane and 3-methyl-3-oxetanemethanol (5.45 g, $53 \mathrm{mmol}$ ). Aqueous $\mathrm{HBr}(48 \%, 7.2 \mathrm{~mL}, 64 \mathrm{mmol})$ was slowly added over a 5-7 min period to give a light yellow solution that was slightly warm to the touch. The solution was refluxed for $3.5 \mathrm{~h}$ and the solvent was removed under vacuum $\left(60{ }^{\circ} \mathrm{C}\right)$ to give $\mathrm{H}_{3} \mathrm{CC}$ $\left(\mathrm{CH}_{2} \mathrm{OH}\right)_{2}\left(\mathrm{CH}_{2} \mathrm{Br}\right)(9.38 \mathrm{~g}, 51 \mathrm{mmol}, 96 \%$ yield $)$ as an orangebrown solid. The product was used in the next step without further purification.

${ }^{1} \mathrm{H}$ NMR $\left(200.1 \mathrm{MHz}, \mathrm{CD}_{2} \mathrm{Cl}_{2}, \delta\right): 3.63\left(\mathrm{~s}, 4 \mathrm{H}, \mathrm{CH}_{2} \mathrm{OH}\right), 3.54$ (s, $2 \mathrm{H}, \mathrm{CH}_{2} \mathrm{Br}$ ), 2.95 (s, $\left.2 \mathrm{H}, \mathrm{OH}\right), 0.91\left(\mathrm{~s}, 3 \mathrm{H}, \mathrm{CH}_{3}\right)$.

A $500 \mathrm{~mL}$ round-bottom Schlenk flask was charged with $\mathrm{H}_{3} \mathrm{CC}\left(\mathrm{CH}_{2} \mathrm{OH}\right)_{2}\left(\mathrm{CH}_{2} \mathrm{Br}\right)(4.08 \mathrm{~g}, 22.3 \mathrm{mmol})$, triethylamine (4.96 g, $0.49 \mathrm{~mol}$ ) and $200 \mathrm{~mL} \mathrm{CH}_{2} \mathrm{Cl}_{2}$. The colourless solution was cooled in an ice bath and neat methanesulfonyl chloride $(5.36 \mathrm{~g}, 47 \mathrm{mmol})$ was added dropwise to give a colourless solution and white precipitate. The solution was stirred for $2 \mathrm{~h}$ 
at $0{ }^{\circ} \mathrm{C}$. The solution was concentrated to $\sim 100 \mathrm{~mL}$ under vacuum and water $(100 \mathrm{~mL})$ was added. The organic layer was extracted and washed with another $100 \mathrm{~mL}$ of water, dried over $\mathrm{MgSO}_{4}$, and the organic solvent was removed under vacuum to obtain $\mathrm{H}_{3} \mathrm{CC}\left(\mathrm{CH}_{2} \mathrm{OMes}\right)_{2}\left(\mathrm{CH}_{2} \mathrm{Br}\right) 7$ (6.14 g, $18 \mathrm{mmol}, 81 \%$ yield) as a thick yellowish oil.

\section{Synthesis of $\mathrm{H}_{3} \mathrm{CC}\left(\mathrm{CH}_{2} \mathrm{PPh}_{2} \cdot \mathrm{BH}_{3}\right)_{2}\left(\mathrm{CH}_{2} \mathrm{OMes}\right)(6-\mathrm{PG})$}

A $500 \mathrm{~mL}$ round-bottom Schlenk flask was charged with $\mathrm{HPPh}_{2}$ (7.99 g, $43 \mathrm{mmol}$ ) and $60 \mathrm{~mL} \mathrm{THF}$. The colourless solution was cooled in an ice bath and $2.5 \mathrm{M} \mathrm{n}$-BuLi in hexane (19 $\mathrm{mL}, 47 \mathrm{mmol}$ ) was added drop wise via syringe to give a red/orange solution. The solution was stirred for $30 \mathrm{~min}$ before being transferred to a $100 \mathrm{~mL}$ addition funnel affixed to a $500 \mathrm{~mL}$ round-bottom Schlenk flask charged with $\mathrm{H}_{3} \mathrm{CC}\left(\mathrm{CH}_{2} \mathrm{O}\right.$ Mes $)_{2}\left(\mathrm{CH}_{2} \mathrm{Br}\right)(7.28 \mathrm{~g}, 21 \mathrm{mmol})$ in $150 \mathrm{~mL}$ THF. The solution was cooled to $-40{ }^{\circ} \mathrm{C}$ and the $\mathrm{LiPPh}_{2}$-solution was added slowly over a $2 \mathrm{~h}$ period. The temperature was maintained at $-40{ }^{\circ} \mathrm{C}$ for $3 \mathrm{~h}$ before being slowly warmed up to room temperature and the orange mixture was stirred overnight. A solution of $\mathrm{BH}_{3} \cdot \mathrm{SMe}_{2}(35 \mathrm{~mL}, 71 \mathrm{mmol})$ in THF $(2.0 \mathrm{M})$ was slowly added to the light yellow reaction mixture. The resulting mixture was stirred for $2 \mathrm{~h}$ and the solvent was removed under vacuum. $250 \mathrm{~mL}$ dietyhlether $(250 \mathrm{~mL})$ and $250 \mathrm{~mL}$ water were added to the white solid. The organic layer was separated and washed with $250 \mathrm{~mL}$ water, dried over $\mathrm{MgSO}_{4}$ and the organic solvent was removed under vacuum. The white solid was loaded onto a silica column $(10 \times 4 \mathrm{~cm})$ and elucidated with a $70: 30$ mixture of ether and petroleum ether. The first fraction was discarded. The second fraction was collected to give $\mathrm{H}_{3} \mathrm{CC}$ $\left(\mathrm{CH}_{2} \mathrm{PPh}_{2} \cdot \mathrm{BH}_{3}\right)_{2}\left(\mathrm{CH}_{2} \mathrm{OMes}\right)$ 6-PG (7.76 g, $14 \mathrm{mmol}$, 65\% yield) as white powder after the solvent was removed under vacuum.

${ }^{31} \mathrm{P}\left\{{ }^{1} \mathrm{H}\right\}$ NMR (81.0 MHz, $\left.\mathrm{CD}_{2} \mathrm{Cl}_{2}, \delta\right): 8.9$ (br, 2P); ${ }^{11} \mathrm{~B}\left\{{ }^{1} \mathrm{H}\right\}$ NMR (128.3 MHz, $\left.\mathrm{CD}_{2} \mathrm{Cl}_{2}, \delta\right):-37.5$ (br, 2B); ${ }^{1} \mathrm{H} \quad \mathrm{NMR}$ (399.9 MHz, $\left.\mathrm{CD}_{2} \mathrm{Cl}_{2}, \delta\right): 7.78-7.73\left(\mathrm{~m}, 4 \mathrm{H}, \mathrm{H}_{o}\right), 7.65-7.60(\mathrm{~m}$, $\left.4 \mathrm{H}, \mathrm{H}_{o}\right), 7.51\left(\mathrm{~m}, 12 \mathrm{H}, \mathrm{H}_{m}\right.$ and $\left.\mathrm{H}_{p}\right), 4.28$ (s, 2H, $\left.\mathrm{CH}_{2} \mathrm{OMs}\right)$, 3.02-2.94 (m, $\left.2 \mathrm{H}, \mathrm{CH}_{2} \mathrm{P}\right), 2.92\left(\mathrm{~s}, 3 \mathrm{H}, \mathrm{SCH}_{3}\right), 2.52-2.45(\mathrm{~m}, 2 \mathrm{H}$, $\mathrm{CH}_{2} \mathrm{P}$ ), 1.15 (broad in baseline, $\left.6 \mathrm{H}, \mathrm{BH}_{3}\right), 0.86\left(\mathrm{~s}, 3 \mathrm{H}, \mathrm{CH}_{3}\right)$; ${ }^{13} \mathrm{C}\left\{{ }^{1} \mathrm{H}\right\}$ NMR (100.6 MHz, $\left.\mathrm{CD}_{2} \mathrm{Cl}_{2}, \delta\right): 132.7\left(\mathrm{~d},{ }^{2} J_{\mathrm{CP}}=9 \mathrm{~Hz}, \mathrm{C}_{o}\right.$ ), $132.2\left(\mathrm{~d},{ }^{2} J_{\mathrm{CP}}=9 \mathrm{~Hz}, \mathrm{C}_{o}\right), 131.8\left(\mathrm{~d},{ }^{4} J_{\mathrm{CP}}=2 \mathrm{~Hz}, \mathrm{C}_{p}\right), 131.7(\mathrm{~d}$, $\left.{ }^{4} J_{\mathrm{CP}}=2 \mathrm{~Hz}, \mathrm{C}_{p}\right), 130.8\left(\mathrm{~d},{ }^{1} J_{\mathrm{CP}}=33 \mathrm{~Hz}, \mathrm{C}_{i}\right), 130.2\left(\mathrm{~d},{ }^{1} J_{\mathrm{CP}}=32\right.$ $\left.\mathrm{Hz}, \mathrm{C}_{i}\right), 129.4\left(\mathrm{~d},{ }^{3} J_{\mathrm{CP}}=2 \mathrm{~Hz}, \mathrm{C}_{m}\right), 129.3\left(\mathrm{~d},{ }^{3} J_{\mathrm{CP}}=2 \mathrm{~Hz}, \mathrm{C}_{m}\right)$, $76.7\left(\mathrm{t},{ }^{3} J_{\mathrm{CP}}=5 \mathrm{~Hz}, \mathrm{CH}_{2} \mathrm{OMs}\right), 40.1(\mathrm{~s}, \mathrm{C}), 37.6\left(\mathrm{~s}, \mathrm{SCH}_{3}\right), 34.9$ $\left(\mathrm{d},{ }^{1} J_{\mathrm{CP}}=6 \mathrm{~Hz}, \mathrm{CH}_{2} \mathrm{P}\right), 34.6\left(\mathrm{~d},{ }^{1} J_{\mathrm{CP}}=6 \mathrm{~Hz}, \mathrm{CH}_{2} \mathrm{P}\right), 23.5\left(\mathrm{t},{ }^{3} J_{\mathrm{CP}}=\right.$ $4 \mathrm{~Hz}, \mathrm{CH}_{3}$ ).

HR-MS (FAB): $[\mathrm{M}]^{+}-\mathrm{BH}_{4}$; theoretical $\mathrm{C}_{30} \mathrm{H}_{34} \mathrm{BO}_{3} \mathrm{P}_{2} \mathrm{~S}$ : 547.1797; experimental 547.1813.

Elemental Analysis Calc. (Found): C 64.08\% (64.5\%), H $6.81 \%(6.95 \%)$.

\section{Synthesis of $\mathrm{H}_{3} \mathrm{CC}\left(\mathrm{CH}_{2} \mathrm{PPh}_{2}\right)_{2}\left(\mathrm{CH}_{2} \mathrm{OMes}\right)(6)$}

A $100 \mathrm{~mL}$ Teflon caped Schlenk flask was charged with $\mathrm{H}_{3} \mathrm{CC}$ $\left(\mathrm{CH}_{2} \mathrm{PPh}_{2} \cdot \mathrm{BH}_{3}\right)_{2}\left(\mathrm{CH}_{2} \mathrm{OMes}\right)(3.16 \mathrm{~g}, 5.6 \mathrm{mmol})$, DABCO (1.89 g, $17 \mathrm{mmol})$ and $20 \mathrm{~mL}$ toluene. The headspace was evacuated and the flask was heated at $80{ }^{\circ} \mathrm{C}$ for $2 \mathrm{~h}$ under static vacuum. The solution was filtered through a small plug of silica $(3 \mathrm{~cm})$ on a glass filter frit and washed with toluene $(3 \times 100 \mathrm{~mL})$. The solvent was removed from the supernatant to give $\mathrm{H}_{3} \mathrm{CC}$ $\left(\mathrm{CH}_{2} \mathrm{PPh}_{2}\right)_{2}\left(\mathrm{CH}_{2} \mathrm{OMes}\right) 6(1.57 \mathrm{~g}, 2.9 \mathrm{mmol}, 52 \%$ yield $)$ as a thick white oil.

${ }^{31} \mathrm{P}\left\{{ }^{1} \mathrm{H}\right\}$ NMR (81.0 MHz, $\left.\mathrm{CD}_{2} \mathrm{Cl}_{2}, \delta\right):-27.2(\mathrm{~s}) ;{ }^{1} \mathrm{H}$ NMR (200.1 MHz, $\left.\mathrm{CD}_{2} \mathrm{Cl}_{2}, \delta\right): 7.47-7.38(\mathrm{~m}, 8 \mathrm{H}, \mathrm{CH}), 7.35-7.27(\mathrm{~m}$, $12 \mathrm{H}, \mathrm{CH}), 4.11$ (s, 2H, $\left.\mathrm{CH}_{2} \mathrm{OMs}\right), 2.70\left(\mathrm{~s}, 3 \mathrm{H}, \mathrm{SCH}_{3}\right), 2.51-2.31$ $\left(\mathrm{m}, 2 \mathrm{H}, \mathrm{CH}_{2} \mathrm{P}\right), 1.00\left(\mathrm{~s}, 3 \mathrm{H}, \mathrm{CH}_{3}\right)$.

\section{Synthesis of $\mathrm{H}_{3} \mathrm{CC}\left(\mathrm{CH}_{2} \mathrm{PPh}_{2} \cdot \mathrm{BH}_{3}\right)_{2}\left(\mathrm{CH}_{2} \mathrm{P}(p \text {-tol })_{2} \cdot \mathrm{BH}_{3}\right)$ (2-PG)}

A $100 \mathrm{~mL}$ round-bottom Schlenk flask was charged with $\mathrm{HP}(p \text {-tol })_{2}(0.344 \mathrm{~g}, 2.1 \mathrm{mmol})$ and $25 \mathrm{~mL}$ THF. The colorless solution was cooled in an ice bath and $2.5 \mathrm{M} n$-BuLi in hexane (0.89 $\mathrm{mL}, 2.2 \mathrm{mmol}$ ) was slowly added via syringe to give a red/ orange solution. The solution was stirred for $30 \mathrm{~min}$ before drop wise addition to a $25 \mathrm{~mL}$ THF solution of $\mathrm{H}_{3} \mathrm{CC}$ $\left(\mathrm{CH}_{2} \mathrm{PPh}_{2}\right)_{2}\left(\mathrm{CH}_{2} \mathrm{OMes}\right)(845 \mathrm{mg}, 1.58 \mathrm{mmol})$ in a $100 \mathrm{~mL}$ round-bottom Schlenk flask cooled to $-40{ }^{\circ} \mathrm{C}$. After the addition the solution was slowly warmed to room temperature and stirred overnight. The reaction mixture was additionally heated to reflux for $2 \mathrm{~h}$. A solution of $\mathrm{BH}_{3} \cdot \mathrm{SMe}_{2}(2.84 \mathrm{~mL}$, $5.69 \mathrm{mmol})$ in THF $(2.0 \mathrm{M})$ was slowly added to the reaction mixture. The resulting mixture was stirred overnight and the volatile compounds were removed under vacuum. $100 \mathrm{~mL} \mathrm{Et}_{2} \mathrm{O}$ and $100 \mathrm{~mL}$ water were added to the white solid. The organic layer was separated and the aqueous layer was extracted with $\mathrm{Et}_{2} \mathrm{O}$ for 2 times. The combined organic layer was washed with $100 \mathrm{~mL}$ water for 2 times, and then dried over $\mathrm{MgSO}_{4}$. After the removal of $\mathrm{Et}_{2} \mathrm{O}$ under vacuum, the white residue in $20 \mathrm{~mL}$ $\mathrm{Et}_{2} \mathrm{O}$ was diffused into hexane to give a white powder. The obtained powder was filtered off and washed 2 times with $10 \mathrm{~mL}$ hexane. After drying in vacuum, $\mathrm{H}_{3} \mathrm{CC}$ $\left(\mathrm{CH}_{2} \mathrm{PPh}_{2} \cdot \mathrm{BH}_{3}\right)_{2}\left(\mathrm{CH}_{2} \mathrm{P}(p \text {-tol })_{2} \cdot \mathrm{BH}_{3}\right)$ 2-PG (0.710 g, $1.02 \mathrm{mmol}$, $65 \%$ yield) was obtained as a white powder.

${ }^{31} \mathrm{P}\left\{{ }^{1} \mathrm{H}\right\}$ NMR (81.0 MHz, $\left.\mathrm{CD}_{2} \mathrm{Cl}_{2}, \delta\right): 9.2$ (br, 2P), 7.4 (br, 1P); ${ }^{1} \mathrm{H}$ NMR (200.1 MHz, $\left.\mathrm{CD}_{2} \mathrm{Cl}_{2}, \delta\right): 7.66-7.37$ (m, $\left.24 \mathrm{H}, \mathrm{CH}\right)$, 7.24-7.19 (m, $4 \mathrm{H}, \mathrm{CH}), 2.93-2.82\left(\mathrm{~m}, 6 \mathrm{H}, \mathrm{CH}_{2} \mathrm{P}\right), 2.36(\mathrm{~s}, 6 \mathrm{H}$, $\mathrm{CH}_{3}$ ), 1.17 (broad in baseline, $\left.9 \mathrm{H}, \mathrm{BH}_{3}\right), 0.79\left(\mathrm{~s}, 3 \mathrm{H}, \mathrm{CH}_{3}\right)$.

Elemental Analysis Calc. (Found): C 74.39\% (73.38\%), H $7.55 \%(7.55 \%)$.

\section{Synthesis of $\mathrm{H}_{3} \mathrm{CC}\left(\mathrm{CH}_{2} \mathrm{PPh}_{2}\right)_{2}\left[\mathrm{CH}_{2} \mathrm{P}(p \text {-tol })_{2}\right]$ (2)}

A $100 \mathrm{~mL}$ Teflon caped Schlenk flask was charged with $\mathrm{H}_{3} \mathrm{CC}$ $\left(\mathrm{CH}_{2} \mathrm{PPh}_{2} \cdot \mathrm{BH}_{3}\right)_{2}\left[\mathrm{CH}_{2} \mathrm{P}(p \text {-tol })_{2} \cdot \mathrm{BH}_{3}\right]$ (11a, $\left.0.689 \mathrm{~g}, 0.99 \mathrm{mmol}\right)$, DABCO $(0.390 \mathrm{~g}, 3.47 \mathrm{mmol})$, and $20 \mathrm{~mL}$ toluene. The headspace was evacuated and the flask was heated at $80^{\circ} \mathrm{C}$ for $2 \mathrm{~h}$ under static vacuum. The solution was filtered through a small plug of silica $(3 \mathrm{~cm})$ on a glass filter frit and washed with toluene $(2 \times 100 \mathrm{~mL})$. The solvent was removed from the supernatant to give $\mathrm{H}_{3} \mathrm{CC}\left(\mathrm{CH}_{2} \mathrm{PPh}_{2}\right)_{2}\left[\mathrm{CH}_{2} \mathrm{P}(p \text {-tol })_{2}\right] 2$ (0.663 g, $0.99 \mathrm{mmol}$, quantitative yield) as a thick white oil.

${ }^{31} \mathrm{P}\left\{{ }^{1} \mathrm{H}\right\}$ NMR $\left(81.0 \mathrm{MHz}, \mathrm{CD}_{2} \mathrm{Cl}_{2}, \delta\right):-28.8\left(\mathrm{t},{ }^{4} J_{\mathrm{PP}}=2.6 \mathrm{~Hz}\right.$, 1P) -26.2 (d); ${ }^{1} \mathrm{H}$ NMR (200.1 MHz, $\left.\mathrm{CD}_{2} \mathrm{Cl}_{2}, \delta\right): 7.38-7.19(\mathrm{~m}$, $26 \mathrm{H}, \mathrm{CH}$ ), 7.10-7.06 (m, $2 \mathrm{H}, \mathrm{CH}), 2.43-2.34\left(\mathrm{~m}, 6 \mathrm{H}, \mathrm{CH}_{2} \mathrm{P}\right)$, 2.31 (s, 6H, $\left.\mathrm{CH}_{3}\right), 0.93\left(\mathrm{~s}, 3 \mathrm{H}, \mathrm{CH}_{3}\right)$. 


\section{Synthesis of RuHCl$\left.(\mathrm{CO})\left\{\mathrm{H}_{3} \mathrm{CC}\left(\mathrm{CH}_{2} \mathrm{PPh}_{2}\right)_{2}\left[\mathrm{CH}_{2} \mathrm{P}(\boldsymbol{p} \text {-tol })_{2}\right]\right\}\right\}$ (B)}

A round-bottom Schlenk flask was charged with $\mathrm{H}_{3} \mathrm{CC}$ $\left.\left(\mathrm{CH}_{2} \mathrm{PPh}_{2}\right)_{2}\left(\mathrm{CH}_{2} \mathrm{P}(p \text {-tol })_{2}\right)\right)(0.663 \mathrm{~g}, 1.0 \mathrm{mmol}), \operatorname{RuHCl}(\mathrm{CO})$ $\left(\mathrm{PPh}_{3}\right)_{3}(0.881 \mathrm{~g}, 0.92 \mathrm{mmol})$ and $40 \mathrm{~mL}$ toluene. The colorless solution with an off white precipitate was heated at reflux for $2 \mathrm{~h}$ to give a light yellow precipitate. The solution was filtered through a filter frit, the yellow residue washed three times with $10 \mathrm{~mL}$ toluene and dried in vacuum to give $\operatorname{RuHCl}(\mathrm{CO})\left\{\mathrm{H}_{3} \mathrm{CC}\right.$ $\left.\left.\left(\mathrm{CH}_{2} \mathrm{PPh}_{2}\right)_{2}\left[\mathrm{CH}_{2} \mathrm{P}(p \text {-tol })_{2}\right]\right\}\right\}$ B $(0.544 \mathrm{~g}, 0.66 \mathrm{mmol}, 72 \%$ yield $)$ as a isomeric mixture.

${ }^{31} \mathrm{P}\left\{{ }^{1} \mathrm{H}\right\}$ NMR $\left(81.0 \mathrm{MHz}, \mathrm{CD}_{2} \mathrm{Cl}_{2}, \delta\right): 48.5\left(\mathrm{dd},{ }^{2} J_{\mathrm{PP}}=40 \mathrm{~Hz}\right.$, $\left.{ }^{2} J_{\mathrm{PP}}=18 \mathrm{~Hz}, 1 \mathrm{P}\right), 48.4\left(\mathrm{dd},{ }^{2} J_{\mathrm{PP}}=40 \mathrm{~Hz},{ }^{2} J_{\mathrm{PP}}=18 \mathrm{~Hz}, 1 \mathrm{P}\right), 46.2$ $\left(\mathrm{dd},{ }^{2} J_{\mathrm{PP}}=40 \mathrm{~Hz},{ }^{2} J_{\mathrm{PP}}=17 \mathrm{~Hz}, 1 \mathrm{P}\right), 13.5\left(\mathrm{dd},{ }^{2} J_{\mathrm{PP}}=40 \mathrm{~Hz},{ }^{2} J_{\mathrm{PP}}=\right.$ $32 \mathrm{~Hz}, 1 \mathrm{P}$ ), 13.3 (dd, ${ }^{2} J_{\mathrm{PP}}=40 \mathrm{~Hz},{ }^{2} J_{\mathrm{PP}}=32 \mathrm{~Hz}, 1 \mathrm{P}$ ), 12.2 (dd, $\left.{ }^{2} J_{\mathrm{PP}}=40 \mathrm{~Hz},{ }^{2} J_{\mathrm{PP}}=32 \mathrm{~Hz}, 1 \mathrm{P}\right), 0.79\left(\mathrm{dd},{ }^{2} J_{\mathrm{PP}}=32 \mathrm{~Hz},{ }^{2} J_{\mathrm{PP}}=18\right.$ $\mathrm{Hz}, 1 \mathrm{P}), 0.58\left(\mathrm{dd},{ }^{2} J_{\mathrm{PP}}=32 \mathrm{~Hz},{ }^{2} J_{\mathrm{PP}}=18 \mathrm{~Hz}, 1 \mathrm{P}\right),-1.4$ (dd, $\left.{ }^{2} J_{\mathrm{PP}}=32 \mathrm{~Hz},{ }^{2} J_{\mathrm{PP}}=18 \mathrm{~Hz}, 1 \mathrm{P}\right) ;{ }^{1} \mathrm{H} \mathrm{NMR}\left(200.1 \mathrm{MHz}, \mathrm{CD}_{2} \mathrm{Cl}_{2}, \delta\right)$ : 7.83-6.53 (m, 28H, CH), 2.36-2.19 (m, 12H, $\mathrm{CH}_{2}$ and $\left.\mathrm{CH}_{3}\right)$, 1.54-1.51 (m, 3H, $\left.\mathrm{CH}_{3}\right),-5.68$ to -6.37 (m, 1H, RuH).

IR (KBr): 512, 697, 739, 837, 1093, 1434, 1483, 1923 (m, $\nu_{\mathrm{Ru}-\mathrm{H}}$ ), 1970 (vs, $\nu_{\mathrm{CO}}$ ), 2918, 2954, $3051 \mathrm{~cm}^{-1}$.

Elemental Analysis Calc. (Found): C 64.58\% (64.16\%), H $5.42 \%(5.32 \%)$.

\section{Improved synthesis of $\mathrm{H}_{3} \mathrm{CC}\left[\mathrm{CH}_{2} \mathrm{P}(p \text {-tol })_{2}\right]_{3}(3)$}

A $500 \mathrm{~mL}$ round-bottom Schlenk flask was charged with $\mathrm{HP}(p \text {-tol })_{2}(3.06 \mathrm{~g}, 14 \mathrm{mmol})$ and $80 \mathrm{~mL}$ THF. The colorless solution was cooled in an ice bath and $2.5 \mathrm{M} n$-BuLi in hexanes ( $6 \mathrm{~mL}, 15 \mathrm{mmol}$ ) was slowly added via syringe to give a red/orange solution. The solution was stirred for $30 \mathrm{~min}$ before drop wise addition to a THF $(100 \mathrm{~mL})$ solution of $\mathrm{H}_{3} \mathrm{CC}$ $\left(\mathrm{CH}_{2} \mathrm{OMes}\right)_{2}\left(\mathrm{CH}_{2} \mathrm{Br}\right)(7,1.21 \mathrm{~g}, 3.6 \mathrm{mmol})$ in a $500 \mathrm{~mL}$ roundbottom Schlenk flask cooled to $-40{ }^{\circ} \mathrm{C}$. The resulting mixture was slowly warmed to room temperature, then heated at reflux overnight. A solution of $\mathrm{BH}_{3} \cdot \mathrm{SMe}_{2}(8.0 \mathrm{~mL}, 16 \mathrm{mmol})$ in THF $(2.0 \mathrm{M})$ was slowly added to the colorless solution. The resulting mixture was stirred for $2 \mathrm{~h}$ and the solvent was removed under vacuum. $100 \mathrm{~mL}$ Ether and $100 \mathrm{~mL}$ water were added to the white solid. The organic layer was separated and washed with $150 \mathrm{~mL}$ water, dried over $\mathrm{MgSO}_{4}$ and the organic solvent was removed under vacuum. The residue was suspended in $20 \mathrm{~mL}$ diethylether, $20 \mathrm{~mL}$ hexane was added, the product filtered off and washed two times with $20 \mathrm{ml}$ hexane. After drying in vacuum $\mathrm{H}_{3} \mathrm{CC}\left[\mathrm{CH}_{2} \mathrm{P}(p \text {-tol })_{2} \cdot \mathrm{BH}_{3}\right]_{3}$ (3-PG, $1.92 \mathrm{~g}$, $2.6 \mathrm{mmol}, 72 \%$ yield) was obtained as a white powder. A $100 \mathrm{~mL}$ Teflon caped Schlenk flask was charged with $\mathrm{H}_{3} \mathrm{CC}$ $\left[\mathrm{CH}_{2} \mathrm{P}(p \text {-tol })_{2} \cdot \mathrm{BH}_{3}\right]_{3}$ (3-PG, $\left.1.92 \mathrm{~g}, 2.6 \mathrm{mmol}\right)$, DABCO (1.58 g, $14.1 \mathrm{mmol})$, and $20 \mathrm{~mL}$ toluene. The headspace was evacuated and the flask was heated at $80{ }^{\circ} \mathrm{C}$ for 2 days under static vacuum. The solution was filtered through a small plug of silica $(3 \mathrm{~cm})$ on a glass filter frit and the product extracted from the residue by washing it twice with $100 \mathrm{~mL}$ toluene. The solvent as removed from the combined organic layers to obtain a thick oil. After trituration of the oil with diethylether, a white powered was formed, which was filtered of and dried in vacuum to give
$\mathrm{H}_{3} \mathrm{CC}\left(\mathrm{CH}_{2} \mathrm{P}(p \text {-tol })_{2}\right)_{3} 3$ (1.03 g, $0.18 \mathrm{mmol}, 72 \%$ yield; $51 \%$ yield overall) as a sticky white solid. All spectroscopic data was consistent with those reported in the literature. ${ }^{8}$

\section{Synthesis of $\operatorname{RuHCl}(\mathrm{CO})\left\{\mathrm{H}_{3} \mathrm{CC}\left[\mathrm{CH}_{2} \mathrm{P}(p \text {-tol })_{2}\right]_{3}\right\}(\mathrm{C})$}

A round-bottom Schlenk flask was charged with $\mathrm{H}_{3} \mathrm{CC}\left(\mathrm{CH}_{2} \mathrm{P}\right.$ $\left.(p \text {-tol })_{2}\right)_{3}(500 \mathrm{mg}, 0.71 \mathrm{mmol}), \operatorname{RuHCl}(\mathrm{CO})\left(\mathrm{PPh}_{3}\right)_{3}(612 \mathrm{mg}$, $0.64 \mathrm{mmol}$ ) and $40 \mathrm{~mL}$ toluene. The colorless solution with an off white precipitate heated at reflux for $2 \mathrm{~h}$ to give a light yellow precipitate. $10 \mathrm{~mL}$ pentane was added to the reaction mixture, the preticipate was filtered off via a sinter frit and washed three times with $10 \mathrm{~mL}$ pentane. After drying in vacuum, $\operatorname{RuHCl}(\mathrm{CO})\left\{\mathrm{H}_{3} \mathrm{CC}\left[\mathrm{CH}_{2} \mathrm{P}(p \text {-tol })_{2}\right]_{3}\right\} \quad$ C $\quad(499 \mathrm{mg}$, $0.57 \mathrm{mmol}, 80 \%$ yield) was obtained as a yellow powder.

${ }^{31} \mathrm{P}\left\{{ }^{1} \mathrm{H}\right\}$ NMR $\left(81.0 \mathrm{MHz}, \mathrm{CD}_{2} \mathrm{Cl}_{2}, \delta\right): 46.5\left(\mathrm{dd},{ }^{2} J_{\mathrm{PP}}=40 \mathrm{~Hz}\right.$, $\left.{ }^{2} J_{\mathrm{PP}}=18 \mathrm{~Hz}, 1 \mathrm{P}\right), 12.6\left(\mathrm{dd},{ }^{2} J_{\mathrm{PP}}=40 \mathrm{~Hz},{ }^{2} J_{\mathrm{PP}}=32 \mathrm{~Hz}\right),-0.8$ $\left({ }^{2} J_{\mathrm{PP}}=32 \mathrm{~Hz},{ }^{2} J_{\mathrm{PP}}=18 \mathrm{~Hz}\right) ;{ }^{1} \mathrm{H} \mathrm{NMR}\left(200.1 \mathrm{MHz}, \mathrm{CD}_{2} \mathrm{Cl}_{2}, \delta\right)$ : 7.73-6.58 (m, $24 \mathrm{H}, \mathrm{CH}), 2.52-2.08\left(\mathrm{~m}, 15 \mathrm{H}, \mathrm{CH}_{2}\right.$ and $\left.\mathrm{CH}_{3}\right)$, 1.50-1.46 (m, 3H, $\left.\mathrm{CH}_{3}\right),-6.02\left(\mathrm{ddd},{ }^{2} J_{\mathrm{HP}}=93.6 \mathrm{~Hz},{ }^{2} J_{\mathrm{HP}}=\right.$ $\left.18.8 \mathrm{~Hz},{ }^{2} J_{\mathrm{HP}}=14.9 \mathrm{~Hz}, 1 \mathrm{H}, \mathrm{RuH}\right)$.

IR (KBr): 521, 558, 624, 713, 735, 804, 838, 1020, 1092, 1190, 1397, 1440, 1499, 1599, 1895 (m, $\nu_{\mathrm{Ru}-\mathrm{H}}$ ), 1979 (vs, $\nu_{\mathrm{CO}}$ ), 2866, 2920, 2948, $3019 \mathrm{~cm}^{-1}$.

Elemental Analysis Calc. (Found): C 65.93\% (65.75\%), H $5.99 \%(6.01 \%)$.

\section{Reaction of RuHCl(CO)(PPh $)_{3}$ with $\mathrm{H}_{3} \mathrm{CC}\left(\mathrm{CH}_{2} \mathrm{PPh}_{2}\right)_{2}$ (2-pyridyl)}

A round-bottom Schlenk flask was charged with $\mathrm{H}_{3} \mathrm{CC}$ $\left(\mathrm{CH}_{2} \mathrm{PPh}_{2}\right)_{2}$ (2-pyridyl) 4 (160 mg, $0.31 \mathrm{mmol}, 1.2$ equiv.), $\left(\mathrm{PPh}_{3}\right)_{3} \mathrm{RuHCl}(\mathrm{CO})$ (250 mg, $0.26 \mathrm{mmol}, 1$ equiv.) and dichloromethane $(40 \mathrm{~mL})$. The light yellow solution was stirred at room temperature for 5 days to light yellow solution. The solution was filtered to remove a small amount of white precipitate and the volume was reduced to $2 \mathrm{~mL}$. A fine yellow precipitate was obtained with the addition of hexane $(\sim 20 \mathrm{~mL})$. The yellow solid contained a mixture of D-1, D-2, and D-3. Recrystallization by slow solvent diffusion of pentane $(20 \mathrm{~mL})$ into a concentrated DCM solution (2 $\mathrm{mL}$ ) gave a small amount of 21 ( $\sim 20 \mathrm{mg})$ in reasonable purity ( 95\%). A second recrystallization attempt of the same sample gave a mixture of D-1, D-2 and D-3. Single crystal of D-3 were isolated from the sample and used for X-ray diffraction analysis.

MS (LIFDI, crude mixture): $m / z$ (\%): 896.2 (100\%, D-1,2 $\mathbf{2}^{+}$ Cl), $669.0\left(25 \%, \mathrm{D}-3^{+}-\mathrm{Cl}\right)$.

D-1: ${ }^{31} \mathrm{P}\left\{{ }^{1} \mathrm{H}\right\}$ NMR (121.4 MHz, $\left.\mathrm{CD}_{2} \mathrm{Cl}_{2}, \delta\right): 44.9\left(\mathrm{dd},{ }^{2} J_{\mathrm{PP}}=\right.$ $\left.280 \mathrm{~Hz},{ }^{2} J_{\mathrm{PP}}=20 \mathrm{~Hz}\right), 28.6\left(\mathrm{dd},{ }^{2} J_{\mathrm{PP}}=280 \mathrm{~Hz},{ }^{2} J_{\mathrm{PP}}=20 \mathrm{~Hz}\right)$, $3.85\left(\mathrm{t},{ }^{2} J_{\mathrm{PP}}=20 \mathrm{~Hz}\right) ;{ }^{1} \mathrm{H} \mathrm{NMR}\left(300.1 \mathrm{MHz}, \mathrm{CD}_{2} \mathrm{Cl}_{2}, \delta\right):-6.55$ $\left(\mathrm{ddd},{ }^{2} J_{\mathrm{HP}}=18 \mathrm{~Hz},{ }^{2} J_{\mathrm{HP}}=22 \mathrm{~Hz},{ }^{2} J_{\mathrm{HP}}=108 \mathrm{~Hz}\right.$ ), all other peaks are overlapping with those of D-2 and D-3.

D-2: ${ }^{31} \mathrm{P}\left\{{ }^{1} \mathrm{H}\right\}$ NMR (121.4 MHz, $\mathrm{CD}_{2} \mathrm{Cl}_{2}, \delta$ ): 45.9 (dd, ${ }^{2} J_{\mathrm{PP}}=$ $\left.230 \mathrm{~Hz},{ }^{2} J_{\mathrm{PP}}=20 \mathrm{~Hz}\right), 34.2\left(\mathrm{dd},{ }^{2} J_{\mathrm{PP}}=230 \mathrm{~Hz},{ }^{2} J_{\mathrm{PP}}=20 \mathrm{~Hz}\right), 9.8$ $\left(\mathrm{t},{ }^{2} J_{\mathrm{PP}}=20 \mathrm{~Hz}\right) ;{ }^{1} \mathrm{H}$ NMR $\left(300.1 \mathrm{MHz}, \mathrm{CD}_{2} \mathrm{Cl}_{2}, \delta\right):-5.19$ (dt, ${ }^{2} J_{\mathrm{HP}}=17 \mathrm{~Hz},{ }^{2} J_{\mathrm{HP}}=92 \mathrm{~Hz}$ ), all other peaks are overlapping with those of D-1 and D-3. 
D-3: ${ }^{31} \mathrm{P}\left\{{ }^{1} \mathrm{H}\right\}$ NMR (121.4 MHz, $\left.\mathrm{CD}_{2} \mathrm{Cl}_{2}, \delta\right): 37.9 \mathrm{ppm}(\mathrm{s}) ;{ }^{1} \mathrm{H}$ NMR (300.1 MHz, $\left.\mathrm{CD}_{2} \mathrm{Cl}_{2}, \delta\right)$ : all peaks are overlapping with those of D-1 and D-2.

\section{Synthesis of RuHCl$(\mathrm{CO})\left(\mathrm{PPh}_{3}\right)\left[\mathrm{H}_{3} \mathrm{CC}\left(\mathrm{CH}_{2} \mathrm{PPh}_{2}\right)_{2}\left(\mathrm{CH}_{2} \mathrm{OH}\right)\right](\mathrm{E})$}

In a glovebox, a round-bottom Schlenk flask was charged with $\mathrm{H}_{3} \mathrm{CC}\left(\mathrm{CH}_{2} \mathrm{PPh}_{2}\right)_{2}\left(\mathrm{CH}_{2} \mathrm{OH}\right) 5(0.502 \mathrm{~g}, 1.1 \mathrm{mmol}), \operatorname{RuHCl}(\mathrm{CO})$ $\left(\mathrm{PPh}_{3}\right)_{3}(952 \mathrm{mg}, 1.0 \mathrm{mmol})$ and $40 \mathrm{~mL}$ toluene. The colorless solution with an off white precipitate heated at reflux for $2 \mathrm{~h}$, then the volume of toluene was reduced under vacuum to ca. $10 \mathrm{~mL}$. In the glovebox, $10 \mathrm{~mL}$ pentane was added to the reaction mixture, forming a pale yellow powder. The precipitate was filtered off via a sinter frit and washed three times with $10 \mathrm{~mL}$ pentane. After drying in vacuum, $\mathrm{RuHCl}(\mathrm{CO})\left(\mathrm{PPh}_{3}\right)\left[\mathrm{H}_{3} \mathrm{CC}\right.$ $\left.\left(\mathrm{CH}_{2} \mathrm{PPh}_{2}\right)_{2}\left(\mathrm{CH}_{2} \mathrm{OH}\right)\right] \mathbf{E}(0.610 \mathrm{~g}, 0.69 \mathrm{mmol}, 69 \%$ yield $)$ was obtained as a pale yellow powder. The ${ }^{31} \mathrm{P}$ NMR indicated that the isolated compounds were the mixture of regioisomers of $\mathbf{E}$.

IR (KBr): 517, 695, 742, 806, 839, 1054, 1091, 1158, 1188, 1312, 1434, 1481, 1586, 1924 (vs, $\nu_{\mathrm{CO}}$ and $\left.\nu_{\mathrm{Ru}-\mathrm{H}}\right), 2928,3053 \mathrm{~cm}^{-1}$.

Elemental Analysis Calc. (Found): C 65.19\% (62.58\%), H $5.24 \%(5.15 \%)$.

${ }^{31} \mathrm{P}\left\{{ }^{1} \mathrm{H}\right\}$ NMR $\left(162.1 \mathrm{MHz}, \mathrm{CD}_{2} \mathrm{Cl}_{2}, \delta\right): 44.2\left(\mathrm{dd},{ }^{2} J_{\mathrm{PP}}=282\right.$ $\left.\mathrm{Hz},{ }^{2} J_{\mathrm{PP}}=20 \mathrm{~Hz}\right), 43.6\left(\mathrm{dd},{ }^{2} J_{\mathrm{PP}}=282 \mathrm{~Hz},{ }^{2} J_{\mathrm{PP}}=20 \mathrm{~Hz}\right), 27.4$ $\left(\mathrm{dd},{ }^{2} J_{\mathrm{PP}}=282 \mathrm{~Hz},{ }^{2} J_{\mathrm{PP}}=20 \mathrm{~Hz}\right), 26.9\left(\mathrm{dd},{ }^{2} J_{\mathrm{PP}}=282 \mathrm{~Hz},{ }^{2} J_{\mathrm{PP}}=\right.$ $20 \mathrm{~Hz}), 3.0\left(\mathrm{t},{ }^{2} J_{\mathrm{PP}}=20 \mathrm{~Hz}\right), 0.4\left(\mathrm{t},{ }^{2} J_{\mathrm{PP}}=20 \mathrm{~Hz}\right)$. All peaks are derived from the regioisomers of $\mathbf{E} ;{ }^{1} \mathrm{H}$ NMR $(400.3 \mathrm{MHz}$, $\mathrm{CD}_{2} \mathrm{Cl}_{2}, \delta$ ): 8.05-6.80 (m, 35H, CH), 3.30-0.18 (m, 9H, $\mathrm{CH}_{2}$ and $\left.\mathrm{CH}_{3}\right),-6.73\left(\mathrm{ddd},{ }^{2} J_{\mathrm{HP}}=109 \mathrm{~Hz},{ }^{2} J_{\mathrm{HP}}=23 \mathrm{~Hz},{ }^{2} J_{\mathrm{HP}}=17 \mathrm{~Hz}, 1 \mathrm{H}\right.$, $\mathrm{RuH}),-6.83\left(\mathrm{ddd},{ }^{2} J_{\mathrm{HP}}=109 \mathrm{~Hz},{ }^{2} J_{\mathrm{HP}}=23 \mathrm{~Hz},{ }^{2} J_{\mathrm{HP}}=17 \mathrm{~Hz}, 1 \mathrm{H}\right.$, $\mathrm{RuH})$. All peaks are derived from the regioisomers of $\mathbf{E}$.

\section{Reaction and RuHCl$(\mathrm{CO})\left(\mathrm{PPh}_{3}\right)\left[\mathrm{H}_{3} \mathrm{CC}\left(\mathrm{CH}_{2} \mathrm{PPh}_{2}\right)_{2}\left(\mathrm{CH}_{2} \mathrm{OH}\right)\right](\mathrm{E})$ with $t$-BuOK}

In a glovebox, a round-bottom Schlenk flask was charged with $\operatorname{RuHCl}(\mathrm{CO})\left(\mathrm{PPh}_{3}\right)\left[\mathrm{H}_{3} \mathrm{CC}\left(\mathrm{CH}_{2} \mathrm{PPh}_{2}\right)_{2}\left(\mathrm{CH}_{2} \mathrm{OH}\right)\right] \quad$ E $\quad(0.114 \mathrm{~g}$, $0.13 \mathrm{mmol}$ ), $t$-BuOK (14.4 $\mathrm{mg}, 0.13 \mathrm{mmol}$ ) and $5 \mathrm{~mL}$ toluene, forming a red solution at room temperature in $2 \mathrm{~h}$. All volatile compounds were removed under vacuum, then $0.5 \mathrm{~mL}$ toluene and $5 \mathrm{~mL}$ pentane was added to a red powder. The resulting suspension was passed through a pad of celite, then a red filtrate was dried under vacuum to give alkoxo ruthenium complex F (81.3 mg, $0.096 \mathrm{mmol}, 75 \%$ yield) as a deep red powder. The ${ }^{1} \mathrm{H}$ and ${ }^{31} \mathrm{P}$ NMR spectra of the obtained powder suggested that it was constituted of mainly alkoxo ruthenium complex $\mathbf{F}$ with some impurities including small amounts of the unreacted $\mathbf{E}$.

Characteristic peaks of $\mathbf{F}$ are described below:

${ }^{31} \mathrm{P}\left\{{ }^{1} \mathrm{H}\right\}$ NMR $\left(243.0 \mathrm{MHz}, d_{8}-\mathrm{THF}, \delta\right): 35.7\left(\mathrm{dd},{ }^{2} J_{\mathrm{PP}}=276\right.$ $\left.\mathrm{Hz},{ }^{2} J_{\mathrm{PP}}=20 \mathrm{~Hz}\right), 33.5\left(\mathrm{dd},{ }^{2} J_{\mathrm{PP}}=276 \mathrm{~Hz},{ }^{2} J_{\mathrm{PP}}=20 \mathrm{~Hz}\right), 13.7$ $\left(\mathrm{dd},{ }^{2} J_{\mathrm{PP}}=20 \mathrm{~Hz}\right) ;{ }^{1} \mathrm{H}$ NMR $\left(600.2 \mathrm{MHz}, d_{8}-\mathrm{THF}, \delta\right):-4.65$ (ddd, $\left.{ }^{2} J_{\mathrm{HP}}=113 \mathrm{~Hz},{ }^{2} J_{\mathrm{HP}}=26 \mathrm{~Hz},{ }^{2} J_{\mathrm{HP}}=13 \mathrm{~Hz}, 1 \mathrm{H}, \mathrm{RuH}\right) . \mathrm{CH}_{3}$ peaks from $t$-Bu group were not observed in ${ }^{1} \mathrm{H}$ NMR spectra.

IR (KBr): 515, 695, 742, 836, 999, 1092, 1186, 1434, 1480, 1586, 1896 (m, $\nu_{\mathrm{Ru}-\mathrm{H}}$ ), 1910 (vs, $\left.\nu_{\mathrm{CO}}\right), 2674,2754,2921,2951$, $3051 \mathrm{~cm}^{-1}$.

MS (LIFDI): $m / z(\%): 848.01\left(100 \%, \mathbf{F}^{+}\right)$.

\section{A representative procedure for catalyst screening described in} Table 1

Entry 1: In an argon-filled glovebox, to a premex autoclave (60 mL, stainless steel) equipped with a magnetically coupled propeller blade stirrer was added $\mathrm{RuHCl}(\mathrm{CO})$ (triphos) $\mathbf{A}$ (36 mg, $0.047 \mathrm{mmol})$, toluene $(17 \mathrm{~mL})$, and 1-octanol $(3.0 \mathrm{~g}$, $24 \mathrm{mmol})$, then the autoclave was sealed. After introducing $\mathrm{NH}_{3}$ gas (7-8 bar) at room temperature, the autoclave was heated to $165{ }^{\circ} \mathrm{C}$ for $15 \mathrm{~h}$ with vigorous stirring (700-800 rpm) without reintroducing $\mathrm{NH}_{3}$ After cooling to the room temperature, the pressurized $\mathrm{NH}_{3}$ gas in the autoclave was released in a fume hood. An aliquot of the reaction mixture was taken for the GC analysis, and the conversion of 1-octanol and the yield of amine products were calculated based on GC area $\%$.

Entry 2: $\operatorname{RuHCl}(\mathrm{CO})\left(\mathrm{PPh}_{3}\right)_{3}(45 \mathrm{mg}, 0.047 \mathrm{mmol})$ and triphos (33 mg, $0.052 \mathrm{mmol}$ ) were used.

Entry 3: RuHCl(CO) $\left(\mathrm{PPh}_{3}\right)_{3}(45 \mathrm{mg}, 0.047 \mathrm{mmol})$ was used.

Entry 4: $\quad \mathrm{RuHCl}(\mathrm{CO})\left\{\mathrm{H}_{3} \mathrm{CC}\left(\mathrm{CH}_{2} \mathrm{PPh}_{2}\right)_{2}\left[\mathrm{CH}_{2} \mathrm{P}(p \text {-tol })_{2}\right]\right\}$ (38 mg, $0.047 \mathrm{mmol}$ ) was used.

Entry 5: $\operatorname{RuHCl}(\mathrm{CO})\left\{\mathrm{H}_{3} \mathrm{CC}\left[\mathrm{CH}_{2} \mathrm{P}(p \text {-tol })_{2}\right]_{3}\right\} \quad(40 \quad \mathrm{mg}$, $0.047 \mathrm{mmol}$ ) was used.

Entry 6: $\mathrm{RuHCl}(\mathrm{CO})\left(\mathrm{PPh}_{3}\right)_{3} \quad(45 \mathrm{mg}, 0.047 \mathrm{mmol})$ and $\mathrm{CH}_{3} \mathrm{C}\left(\mathrm{CH}_{2} \mathrm{PPh}_{2}\right)_{2}$ (2-pyridyl) $4(26 \mathrm{mg}, 0.046 \mathrm{mmol})$ were used.

Entry 7: $\mathrm{RuHCl}(\mathrm{CO})\left(\mathrm{PPh}_{3}\right)\left[\mathrm{H}_{3} \mathrm{CC}\left(\mathrm{CH}_{2} \mathrm{PPh}_{2}\right)_{2}\left(\mathrm{CH}_{2} \mathrm{OH}\right)\right] \quad$ E (41 mg, $0.047 \mathrm{mmol}$ ) was used.

Entry 8: The proposed alkoxo-ruthenium complex F $(20 \mathrm{mg}$, $0.023 \mathrm{mmol})$, toluene (8.5 mL), and 1-octanol (1.5 g, $12 \mathrm{mmol}$ ) were used.

Entry 9: RuHCl(CO) $\left(\mathrm{PPh}_{3}\right)_{3}(45 \mathrm{mg}, 0.047 \mathrm{mmol})$ and $\mathrm{CH}_{3} \mathrm{C}$ $\left(\mathrm{CH}_{2} \mathrm{PPh}_{2}\right)_{2}\left(\mathrm{CH}_{2} \mathrm{OMs}\right) 6$ (28 $\left.\mathrm{mg}, 0.052 \mathrm{mmol}\right)$ were used.

Entry 10: $\operatorname{RuHCl}(\mathrm{CO})\left(\mathrm{PPh}_{3}\right)_{3}(45 \mathrm{mg}, 0.047 \mathrm{mmol})$ and dppdmp (23 mg, $0.052 \mathrm{mmol}$ ) were used.

Entry 11: RuHCl(CO) $\left(\mathrm{PPh}_{3}\right)_{3}(45 \mathrm{mg}, 0.047 \mathrm{mmol})$ and dppp (21 mg, $0.052 \mathrm{mmol}$ ) were used.

Entry 12: $\mathrm{RuHCl}(\mathrm{CO})\left(\mathrm{PPh}_{3}\right)_{3}$ (45 mg, $\left.0.047 \mathrm{mmol}\right)$, dppp (21 $\mathrm{mg}, 0.052 \mathrm{mmol})$, and toluene $(6 \mathrm{~mL})$ were used.

Entry 13: $\mathrm{RuHCl}(\mathrm{CO})\left(\mathrm{PPh}_{3}\right)_{3}$ (45 mg, $\left.0.047 \mathrm{mmol}\right)$, dppp (21 $\mathrm{mg}, 0.052 \mathrm{mmol})$, toluene $(6 \mathrm{~mL})$, and $\mathrm{p}\left(\mathrm{NH}_{3}\right)=4$ bar (53 mmol of $\mathrm{NH}_{3}$ ) were used.

\section{Acknowledgements}

CaRLa (Catalyst Research Laboratory) is co-financed by Ruprechts-Karls-University Heidelberg (Heidelberg University) and BASF SE.

\section{Notes and references}

1 (a) B. R. Brown, The Organic Chemistry of Aliphatic Nitrogen Compounds, Oxford University, New York, 1994; (b) S. A. Lawrence, Amines: Synthesis, Properties and Applications, Cambridge University Press, Cambridge, 2005; 
(c) P. Roose, K. Eller, E. Henkes, R. Rossbacher and H. Höke, Amines, Aliphatic: Ullmann's Encyclopedia of Industrial Chemistry, Wiley-VCH, Weinheim, 2015.

2 R. N. Salvatore, C. H. Yoon and K. W. Jung, Tetrahedron, 2001, 57, 7785 .

3 (a) J. Kim, H. J. Kim and S. Chang, Eur. J. Org. Chem., 2013, 3201; (b) J. L. Klinkenberg and J. F. Hartwig, Angew. Chem., Int. Ed., 2011, 50, 86; (c) S. Bähn, S. Imm, L. Neubert, M. Zhang, H. Neumann and M. Beller, ChemCatChem, 2011, 3, 1853.

4 Recent reviews, see: (a) S. Bähn, S. Imm, L. Neubert, M. Zhang, H. Neumann and M. Beller, ChemCatChem, 2011, 3, 1852; (b) C. Gunanathan and D. Milstein, Chem. Rev., 2014, 114, 12024; (c) K. Shimizu, Catal. Sci. Technol., 2015, 5, 1412; (d) Q. Yang, Q. Wang and Z. Yu, Chem. Soc. Rev., 2015, 44, 2305.

5 (a) C. Gunanathan and D. Milstein, Angew. Chem., Int. Ed., 2008, 47, 8661; (b) D. Pingen, C. Müller and D. Vogt, Angew. Chem., Int. Ed., 2010, 49, 8130; (c) S. Imm, S. Bähn, L. Neubert, H. Neumann and M. Beller, Angew. Chem., Int. Ed., 2010, 49, 8126; (d) G. Walther, J. Deutsch, A. Martin, F. E. Baumann, D. Fridag, R. Franke and A. Köckritz, ChemSusChem, 2011, 4, 1052; (e) W. Baumann, A. Spannenberg, J. Pfeffer, T. Haas, A. Köckritz, A. Martin and J. Deutsch, Chem. - Eur. J., 2013, 19, 17702; $(f)$ D. Pingen, O. Diebolt and D. Vogt, ChemCatChem, 2013, 5, 2905; $(g)$ D. Pingen, M. Lutz and D. Vogt, Organometallics, 2014, 33, 1623; (h) X. Ye, P. N. Plessow, M. K. Brinks, M. Schelwies, T. Schaub, F. Rominger, R. Paciello, M. Limbach and P. Hofmann, J. Am. Chem. Soc., 2014, 136, 5923.

6 E. Balaraman, D. Srimani, Y. D. Posner and D. Milstein, Catal. Lett., 2015, 145, 139.

7 (a) S. Imm, S. Bähn, M. Zhang, L. Neubert, H. Neumann, F. Klasovsky, J. Pfeffer, T. Haas and M. Beller, Angew. Chem., Int. Ed., 2011, 50, 7599; (b) E. J. Derrah, M. Hanauer, P. N. Plessow, M. Schelwies, M. K. da Silva and T. Schaub, Organometallics, 2015, 34, 1872; (c) T. Schaub, B. Buschhaus, M. K. Brinks, M. Schelwies, R. Paciello, J. P. Melder and M. Merger, WO 2012119927, 2012.
8 (a) H. Heidel, G. Huttner and G. Helmchen, Z. Naturforsch., B: Chem. Sci., 1993, 48, 1681; (b) A. Muth, O. Walter, G. Huttner, A. Asam, L. Zsolnai and C. Emerich, J. Organomet. Chem., 1994, 468, 149.

9 S. Doherty, E. G. Robins, M. Nieuwenhuyzen, P. A. Champkin and W. Clegg, Organometallics, 2002, 21, 4147.

10 (a) T. Seitz, A. Muth and G. Huttner, Chem. Ber., 1994, 127, 1837; (b) Y.-T. Hsieh, C.-M. Cheng, M.-S. Peng and T.-S. Liu, J. Chem. Soc., Dalton Trans., 1994, 3499.

11 Attempts to install other diorganophosphino moiety or

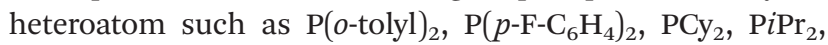
and $\mathrm{NH}_{2}$, were unsuccessful by using our approach.

12 K.-M. Sung, S. Huh and J.-M. Jun, Polyhedron, 1999, 18, 469.

13 RuHCl(CO)(triphos) A was characterised by X-ray analysis, see: S. Savourey, G. Lefèvre, J.-C. Berthert, P. Thuéry, C. Genre and T. Contat, Angew. Chem., Int. Ed., 2014, 53, 10466.

14 Preparation and characterization of $\mathrm{RuHCl}(\mathrm{CO})(\mathrm{dppp})$ $\left(\mathrm{PPh}_{3}\right)$ from $\mathrm{RuHCl}(\mathrm{CO})\left(\mathrm{PPh}_{3}\right)_{3}$ and dppp was reported, see: (a) A. Santos, J. López, J. Montoya, P. Noheda, A. Romero and A. M. Echavarren, Organometallics, 1994, 13, 3605; (b) S. Huh, Y. Cho and J.-M. Jun, Polyhedron, 1994, 13, 1887.

15 Cyclohexanol and ammonia undergo the selective nomoalkylation with dppp ligand. See ref. $5 e$.

16 In Fig. 6, $\mathrm{P}\left(\mathrm{NH}_{3}\right)=4.1-4.5$ bar was used, which corresponded to approximately $53 \mathrm{mmol}$ of $\mathrm{NH}_{3}$ in the autoclave.

17 (a) R. Yamaguchi, S. Kawagoe, C. Asai and K. Fujita, Org. Lett., 2008, 10, 181; (b) R. Kawahara, K. Fujita and R. Yamaguchi, J. Am. Chem. Soc., 2010, 132, 15108; (c) S. Wöckel, M. Schelweis, M. K. Brinks, F. Rominger, P. Hofmann and M. Limbach, Org. Lett., 2013, 15, 266.

18 Program SADABS 2012/1 for absorption correction, see: G. M. Sheldrick, Bruker Analytical X-Ray Division, Madison, Wisconsin, 2012.

19 L. Gonzáles-Sebastián, M. Flores-Alamo and J. J. García, Organometallics, 2012, 31, 8200. 